\title{
In Search of Distress Risk
}

\section{Citation}

Campbell, John Y., Jens Hilscher, and Jan Szilagyi. 2008. In Search of Distress Risk. Journal of Finance 63, no. 6: 2899-2939.

\section{Published Version}

http://dx.doi.org/10.1111/j.1540-6261.2008.01416.x

\section{Permanent link}

http://nrs.harvard.edu/urn-3:HUL.InstRepos:3199070

\section{Terms of Use}

This article was downloaded from Harvard University's DASH repository, and is made available under the terms and conditions applicable to Other Posted Material, as set forth at http:// nrs.harvard.edu/urn-3:HUL.InstRepos:dash.current.terms-of-use\#LAA

\section{Share Your Story}

The Harvard community has made this article openly available.

Please share how this access benefits you. Submit a story.

Accessibility 

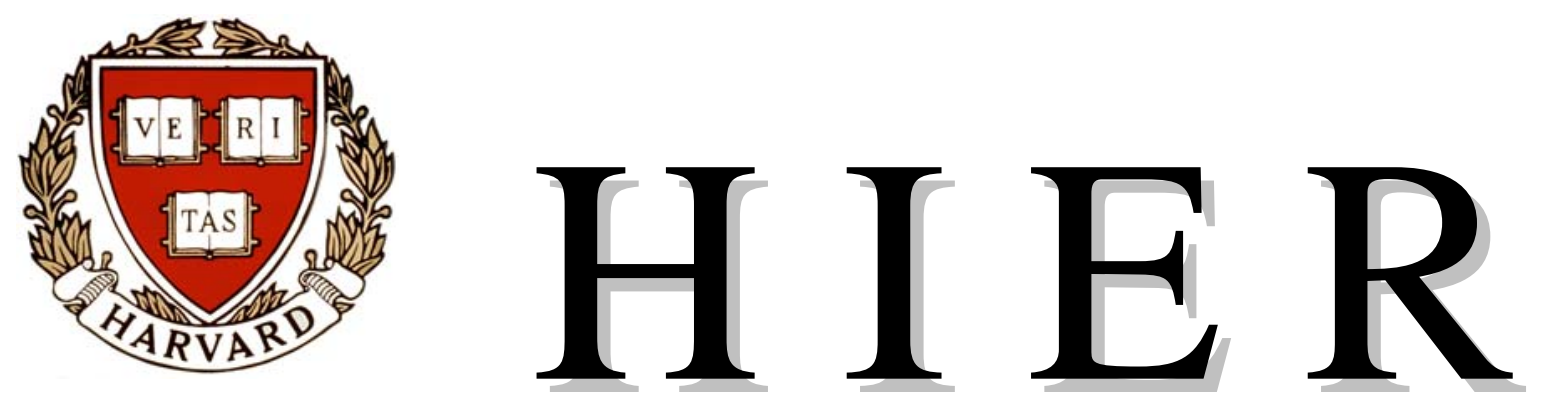

\title{
Harvard Institute of Economic Research
}

\author{
Discussion Paper Number 2081 \\ In Search of Distress Risk \\ by \\ John Y. Campbell, Jens Hilscher \\ and Jan Szilagyi \\ July 2005

\section{Harvard University Cambridge, Massachusetts}

This paper can be downloaded without charge from:

http://post.economics.harvard.edu/hier/2005papers/2005list.html

The Social Science Research Network Electronic Paper Collection: http://ssrn.com/abstract $=770805$ 


\title{
In Search of Distress Risk
}

\author{
John Y. Campbell, Jens Hilscher, and Jan Szilagyi ${ }^{1}$
}

First draft: October 2004

This version: June 27, 2005

\footnotetext{
${ }^{1}$ Corresponding author: John Y. Campbell, Department of Economics, Littauer Center 213, Harvard University, Cambridge MA 02138, USA, and NBER. Tel 617-496-6448, email john_campbell@harvard.edu. This material is based upon work supported by the National Science Foundation under Grant No. 0214061 to Campbell. We would like to thank Robert Jarrow and Don van Deventer of Kamakura Risk Information Services (KRIS) for providing us with data on corporate bankruptcies and failures, and Stuart Gilson, John Griffin, Scott Richardson, Ulf von Kalckreuth, and seminar participants at Humboldt Universität zu Berlin, HEC Paris, the University of Texas, the Wharton School, and the Deutsche Bundesbank 2005 Spring Conference for helpful discussion.
} 


\begin{abstract}
This paper explores the determinants of corporate failure and the pricing of financially distressed stocks using US data over the period 1963 to 2003. Firms with higher leverage, lower profitability, lower market capitalization, lower past stock returns, more volatile past stock returns, lower cash holdings, higher market-book ratios, and lower prices per share are more likely to file for bankruptcy, be delisted, or receive a $\mathrm{D}$ rating. When predicting failure at longer horizons, the most persistent firm characteristics, market capitalization, the market-book ratio, and equity volatility become relatively more significant. Our model captures much of the time variation in the aggregate failure rate. Since 1981, financially distressed stocks have delivered anomalously low returns. They have lower returns but much higher standard deviations, market betas, and loadings on value and small-cap risk factors than stocks with a low risk of failure. These patterns hold in all size quintiles but are particularly strong in smaller stocks. They are inconsistent with the conjecture that the value and size effects are compensation for the risk of financial distress.
\end{abstract}




\section{Introduction}

The concept of financial distress is often invoked in the asset pricing literature to explain otherwise anomalous patterns in the cross-section of stock returns. The idea is that certain companies have an elevated risk that they will fail to meet their financial obligations, and investors charge a premium for bearing this risk. ${ }^{2}$

While this idea has a certain plausibility, it leaves a number of basic questions unanswered. First, how do we measure the failure to meet financial obligations? Second, how do we measure the probability that a firm will fail to meet its financial obligations? Third, even if we have answered these questions and thereby constructed an empirical measure of financial distress, is it the case that the stock prices of financially distressed companies move together in response to a common risk factor? Finally, what returns have financially distressed stocks provided historically? Is there any evidence that financial distress risk carries a premium?

In this paper we consider two alternative ways in which a firm may fail to meet its financial obligations. First, we look at bankruptcy filings under either Chapter 7 or Chapter 11 of the bankruptcy code. Second, we look at failures, defined more broadly to include bankruptcies, delistings, or D ("default") ratings issued by a leading credit rating agency. The broader definition of failure allows us to capture at least some cases where firms avoid bankruptcy by negotiating with creditors out of court (Gilson, John, and Lang 1990, Gilson 1997). It also captures firms that perform so poorly that their stocks are delisted from the exchange, an event which sometimes precedes bankruptcy or formal default.

To measure the probability that a firm enters either bankruptcy or failure, we adopt a relatively atheoretical econometric approach. We estimate a dynamic panel model using a logit specification, following Shumway (2001), Chava and Jarrow (2004), and others. We extend the previous literature by considering a wide range of explanatory variables, including both accounting and equity-market variables, and by explicitly considering how the optimal specification varies with the horizon of the

\footnotetext{
${ }^{2}$ Chan and Chen (1991), for example, attribute the size premium to the prevalence of "marginal firms" in small-stock portfolios, and describe marginal firms as follows: "They have lost market value because of poor performance, they are inefficient producers, and they are likely to have high financial leverage and cash flow problems. They are marginal in the sense that their prices tend to be more sensitive to changes in the economy, and they are less likely to survive adverse economic conditions." Fama and French (1996) use the term "relative distress" in a similar fashion.
} 
forecast. Some papers on bankruptcy concentrate on predicting the event that a bankruptcy will occur during the next month. Over such a short horizon, it should not be surprising that the recent return on a firm's equity is a powerful predictor, but this may not be very useful information if it is relevant only in the extremely short run, just as it would not be useful to predict a heart attack by observing a person dropping to the floor clutching his chest. We also explore time-series variation in the number of bankruptcies, and ask how much of this variation is explained by changes over time in the variables that predict bankruptcy at the firm level.

Our empirical work begins with monthly bankruptcy and failure indicators provided by Kamakura Risk Information Services (KRIS). The bankruptcy indicator was used by Chava and Jarrow (2004), and covers the period from January 1963 through December 1998. The failure indicator runs from January 1963 through December 2003. We merge these datasets with firm level accounting data from COMPUSTAT as well as monthly and daily equity price data from CRSP. This gives us about 800 bankruptcies, 1600 failures, and predictor variables for 1.7 million firm months.

We start by estimating a basic specification used by Shumway (2001) and similar to that of Chava and Jarrow (2004). The model includes both equity market and accounting data. From the equity market, we measure the excess stock return of each company over the past month, the volatility of daily stock returns over the past three months, and the market capitalization of each company. From accounting data, we measure net income as a ratio to assets, and total leverage as a ratio to assets. We obtain similar coefficient estimates whether we are predicting bankruptcies through 1998, failures through 1998, or failures through 2003.

From this starting point, we make a number of contributions to the prediction of corporate bankruptcies and failures. First, we explore some sensible modifications to the variables listed above. Specifically, we show that scaling net income and leverage by the market value of assets rather than the book value, and adding further lags of stock returns and net income, can improve the explanatory power of the benchmark regression.

Second, we explore some additional variables and find that corporate cash holdings, the market-book ratio, and a firm's price per share contribute explanatory power. In a related exercise we construct a measure of distance to default, based on the practitioner model of KMV (Crosbie and Bohn 2001) and ultimately on the structural default model of Merton (1974). We find that this measure adds relatively little 
explanatory power to the reduced-form variables already included in our model. ${ }^{3}$

Third, we examine what happens to our specification as we increase the horizon at which we are trying to predict failure. Consistent with our expectations, we find that our most persistent forecasting variable, market capitalization, becomes relatively more important as we predict further into the future. Volatility and the market-book ratio also become more important at long horizons relative to net income, leverage, and recent equity returns.

Fourth, we study time-variation in the number of failures. We compare the realized frequency of failure to the predicted frequency over time. Although the model underpredicts the frequency of failure in the 1980s and overpredicts it in the 1990s, the model fits the general time pattern quite well.

Finally, we use our fitted probability of failure as a measure of financial distress and calculate the risks and average returns on portfolios of stocks sorted by this fitted probability. We find that financially distressed firms have high market betas and high loadings on the HML and SMB factors proposed by Fama and French $(1993,1996)$ to capture the value and size effects. However they do not have high average returns, suggesting that the equity market has not properly priced distress risk.

There is a large related literature that studies the prediction of corporate bankruptcy. The literature varies in choice of variables to predict bankruptcy and the methodology used to estimate the likelihood of bankruptcy. Altman (1968), Ohlson (1980), and Zmijewski (1984) use accounting variables to estimate the probability of bankruptcy in a static model. Altman's Z-score and Ohlson's O-score have become popular and widely accepted measures of financial distress. They are used, for example, by Dichev (1998), Griffin and Lemmon (2002), and Ferguson and Shockley (2003) to explore the risks and average returns for distressed firms.

Shumway (2001) estimates a hazard model at annual frequency and adds equity market variables to the set of scaled accounting measures used in the earlier literature. He points out that estimating the probability of bankruptcy in a static setting introduces biases and overestimates the impact of the predictor variables. This is because the static model does not take into account that a firm could have had unfavorable indicators several periods before going into bankruptcy. Hillegeist, Cram, Keating and

\footnotetext{
${ }^{3}$ This finding is consistent with recent results of Bharath and Shumway (2004), circulated after the first version of this paper.
} 
Lunstedt (2004) summarize equity market information by calculating the probability of bankruptcy implied by the structural Merton model. Adding this to accounting data increases the accuracy of bankruptcy prediction within the framework of a hazard model. Chava and Jarrow (2004) estimate hazard models at both annual and monthly frequencies and find that the accuracy of bankruptcy prediction is greater at a monthly frequency. They also compare the effects of accounting information across industries.

Duffie and Wang (2003) emphasize that the probability of bankruptcy depends on the horizon one is considering. They estimate mean-reverting time series processes for a macroeconomic state variable - personal income growth - and a firm-specific variable distance to default. They combine these with a short-horizon bankruptcy model to find the marginal probabilities of default at different horizons. Using data from the US industrial machinery and instruments sector, they calculate term structures of default probabilities. We conduct a similar exercise using a reducedform econometric approach; we do not model the time-series evolution of the predictor variables but instead directly estimate longer-term default probabilities.

The remainder of the paper is organized as follows. Section 2 describes the construction of the data set, outlier analysis and summary statistics. Section 3 discusses our basic dynamic panel model, extensions to it, and the results from estimating the model at one-month and longer horizons. We find that market capitalization, the market-book ratio, and equity volatility become relatively more significant as the horizon increases. This section also considers the ability of the model to fit the aggregate time-series of failures. Section 4 studies the return properties of equity portfolios formed on the fitted value from our bankruptcy prediction model. We ask whether stocks with high bankruptcy probability have unusually high or low returns relative to the predictions of standard cross-sectional asset pricing models such as the CAPM or the three-factor Fama-French model. Section 5 concludes. 


\section{Data description}

In order to estimate a dynamic logit model we need an indicator of financial distress and a set of explanatory variables. The bankruptcy indicator we use is taken from Chava and Jarrow (2004); it includes all bankruptcy filings in the Wall Street Journal Index, the SDC database, SEC filings and the $\mathrm{CCH}$ Capital Changes Reporter. The indicator equals one in a month in which a firm filed for bankruptcy under Chapter 7 or Chapter 11, and zero otherwise; in particular, the indicator is zero if the firm disappears from the dataset for some reason other than bankruptcy such as acquisition or delisting. The data span the months from January 1963 through December 1998. We also consider a broader failure indicator, which equals one if a firm files for bankruptcy, delists, or receives a D rating, over the period January 1963 through December 2003.

Table 1 summarizes the properties of our bankruptcy and failure indicators. The first column shows the number of active firms for which we have data in each year. The second column shows the number of bankruptcies, and the third column the corresponding percentage of active firms that went bankrupt in each year. The fourth and fifth columns repeat this information for our failure series.

It is immediately apparent that bankruptcies were extremely rare until the late 1960's. In fact, in the three years 1967-1969 there were no bankruptcies at all in our dataset. The bankruptcy rate increased in the early 1970's, and then rose dramatically during the 1980's to a peak of $1.5 \%$ in 1986 . It remained high through the economic slowdown of the early 1990's, but fell in the late 1990's to levels only slightly above those that prevailed in the 1970's.

Some of these changes through time are probably the result of changes in the law governing corporate bankruptcy in the 1970's, and related financial innovations such as the development of below-investment-grade public debt (junk bonds) in the 1980's and the advent of prepackaged bankruptcy filings in the early 1990's (Tashjian, Lease, and McConnell 1996). Changes in corporate capital structure (Bernanke and Campbell 1988) and the riskiness of corporate activities (Campbell, Lettau, Malkiel, and $\mathrm{Xu} 2001$ ) are also likely to have played a role, and one purpose of our investigation is to quantify the time-series effects of these changes.

The broader failure indicator tracks the bankruptcy indicator closely until the early 1980's, but towards the end of the sample it begins to diverge significantly. The 
number of failures increases dramatically after 1998, reflecting the financial distress of many young firms that were newly listed during the boom of the late 1990's.

In order to construct explanatory variables at the individual firm level, we combine quarterly accounting data from COMPUSTAT with monthly and daily equity market data from CRSP. From COMPUSTAT we construct a standard measure of profitability: net income relative to total assets. Previous authors have measured total assets at book value, but we find better explanatory power when we measure the equity component of total assets at market value by adding the book value of liabilities to the market value of equities. We call this series NIMTA (Net Income to Market-valued Total Assets) and the traditional series NITA (Net Income to Total Assets). We also use COMPUSTAT to construct a measure of leverage: total liabilities relative to total assets. We again find that a market-valued version of this series, defined as total liabilities divided by the sum of market equity and book liabilities, performs better than the traditional book-valued series. We call the two series TLMTA and TLTA, respectively. To these standard measures of profitability and leverage, we add a measure of liquidity, the ratio of a company's cash and short-term assets to the market value of its assets (CASHMTA). We also calculate each firm's market-to-book ratio (MB).

In constructing these series we adjust the book value of assets to eliminate outliers, following the procedure suggested by Cohen, Polk, and Vuolteenaho (2003). That is, we add $10 \%$ of the difference between market and book equity to the book value of total assets, thereby increasing book values that are extremely small, probably mismeasured, and create outliers when used as the denominators of financial ratios. We also winsorize all variables at the 5 th and 95 th percentiles of their cross-sectional distributions. That is, we replace any observation below the 5 th percentile with the 5 th percentile, and any observation above the 95 th percentile with the 95 th percentile. We are careful to adjust each company's fiscal year to the calendar year and lag the accounting data by two months. This adjustment ensures that the accounting data are available at the beginning of the month over which bankruptcy is measured. The Appendix to this paper describes the construction of these variables in greater detail.

We add several market-based variables to these two accounting variables. We calculate the monthly log excess return on each firm's equity relative to the S\&P 500 index (EXRET), the standard deviation of each firm's daily stock return over the past three months (SIGMA), and the relative size of each firm measured as the log ratio of its market capitalization to that of the S\&P 500 index (RSIZE). Finally, 
we calculate each firm's log price per share, truncated above at $\$ 15$ (PRICE). This captures a tendency for distressed firms to trade at low prices per share, without reverse-splitting to bring price per share back into a more normal range.

\subsection{Summary statistics}

Table 2 summarizes the properties of our ten main explanatory variables. The first panel in Table 2 describes the distributions of the variables in almost 1.7 million firmmonths with complete data availability, the second panel describes a much smaller sample of almost 800 bankruptcy months, and the third panel describes just over 1600 failure months. ${ }^{4}$

In interpreting these distributions, it is important to keep in mind that we weight every firm-month equally. This has two important consequences. First, the distributions are dominated by the behavior of relatively small companies; value-weighted distributions look quite different. Second, the distributions reflect the influence of both cross-sectional and time-series variation. The cross-sectional averages of several variables, in particular NIMTA, TLMTA, and SIGMA, have experienced significant trends since 1963: SIGMA and TLMTA have trended up, while NIMTA has trended down. The downward trend in NIMTA is not just a consequence of the buoyant stock market of the 1990's, because book-based net income, NITA, displays a similar trend. The influence of these trends is magnified by the growth in the number of companies and the availability of quarterly accounting data over time, which means that recent years have greater influence on the distribution than earlier years. In particular, there is a scarcity of quarterly Compustat data before the early 1970's so years before 1973 have very little influence on our empirical results.

These facts help to explain several features of Table 2. The mean level of NIMTA, for example, is almost exactly zero (in fact, very slightly negative). This is lower than the median level of NIMTA, which is positive at $0.6 \%$ per quarter or $2.4 \%$ at an annual rate, because the distribution of profitability is negatively skewed. The gap between mean and median is even larger for NITA. All these measures of profitability are strikingly low, reflecting the prevalence of small, unprofitable listed companies in recent years. Value-weighted mean profitability is considerably higher. In addition,

\footnotetext{
${ }^{4}$ For a firm-month to be included in Table 2, we must observe leverage, profitability, excess return, and market capitalization. We do not require a valid measure of volatility, and replace SIGMA with its cross-sectional mean when this variable is missing.
} 
the distributions of NIMTA and NITA have large spikes just above zero, a phenomenon noted by Hayn (1995), suggesting that firms may be managing their earnings to avoid reporting losses. ${ }^{5}$

The average value of EXRET is -0.011 or $-1.1 \%$ per month. This extremely low number reflects both the underperformance of small stocks during the later part of our sample period (the value-weighted mean is almost exactly zero), and the fact that we are reporting a geometric average excess return rather than an arithmetic average. The difference is substantial because individual stock returns are extremely volatile. The average value of the annualized firm-level volatility SIGMA is $56 \%$, again reflecting the strong influence of small firms and recent years in which idiosyncratic volatility has been high (Campbell, Lettau, Malkiel, and Xu 2001).

A comparison of the top and the second panel of Table 2 reveals that bankrupt firms have intuitive differences from the rest of the sample. In months immediately preceding a bankruptcy filing, firms typically make losses (the mean loss is $4.0 \%$ quarterly or $16 \%$ of market value of assets at an annual rate, and the median loss is $4.7 \%$ quarterly or almost $19 \%$ at an annual rate); the value of their debts is extremely high relative to their assets (average leverage is almost 80\%, and median leverage exceeds $87 \%$ ); they have experienced extremely negative returns over the past month (the mean is $-11.5 \%$ over a month, while the median is $-17 \%$ over a month); and their volatility is extraordinarily high (the mean annualized volatility is $106 \%$ and the median is 126\%). Bankrupt firms also tend to be relatively small (about 7 times smaller than other firms on average, and 10 times smaller at the median), and they have only about half as much cash and short-term investments, in relation to the market value of assets, as non-bankrupt firms.

The market-book ratio of bankrupt firms has a similar mean but a much higher standard deviation than the market-book ratio of other firms. It appears that some firms go bankrupt after realized losses have driven down their book values relative to market values, while others go bankrupt after bad news about future prospects has driven down their market values relative to book values. Thus bankruptcy is associated with a wide spread in the market-book ratio.

Finally, firms that go bankrupt typically have low prices per share. The mean

\footnotetext{
${ }^{5}$ There is a debate in the accounting literature about the interpretation of this spike. Burgstahler and Dichev (1997) argue that it reflects earnings management, but Dechow, Richardson, and Tuna (2003) point out that discretionary accruals are not associated with the spike in the manner that would be expected if this interpretation is correct.
} 
price per share is just over $\$ 1.50$ for a bankrupt firm, while the median price per share is slightly below $\$ 1$.

The third panel of Table 2 reports the summary statistics for our failure sample through December 2003. The patterns are similar to those in the second panel, but some effects are stronger for failures than for bankruptcies (losses are more extreme, volatility is higher, price per share is lower, and market capitalization is considerably smaller), while other effects are weaker (leverage is less extreme and cash holdings are higher). 


\section{A logit model of bankruptcy and failure}

The summary statistics in Table 2 show that bankrupt and failed firms have a number of unusual characteristics. However the number of bankruptcies and failures is tiny compared to the number of firm-months in our dataset, so it is not at all clear how useful these variables are in predicting bankruptcy. Also, these characteristics are correlated with one another and we would like to know how to weight them optimally. Following Shumway (2001) and Chava and Jarrow (2004), we now estimate the probabilities of bankruptcy and failure over the next period using a logit model.

We assume that the marginal probability of bankruptcy or failure over the next period follows a logistic distribution and is given by

$$
P_{t-1}\left(Y_{i t}=1\right)=\frac{1}{1+\exp \left(-\alpha-\beta x_{i, t-1}\right)}
$$

where $Y_{i t}$ is an indicator that equals one if the firm goes bankrupt or fails in month $t$, and $x_{i, t-1}$ is a vector of explanatory variables known at the end of the previous month. A higher level of $\alpha+\beta x_{i, t-1}$ implies a higher probability of bankruptcy or failure.

Table 3 reports logit regression results for various alternative specifications. In the first three columns we follow Shumway (2001) and Chava and Jarrow (2004), and estimate a model with five standard variables: NITA, TLTA, EXRET, SIGMA, and RSIZE. This model measures assets in the conventional way, using annual book values from COMPUSTAT. It excludes firm age, a variable which Shumway (2001) considered but found to be insignificant in predicting bankruptcy. Column 1 estimates the model for bankruptcy over the period 1963-1998, column 2 estimates it for failure over the same period, and column 3 looks at failure over the entire 1963-2003 period.

All five of the included variables in the Shumway (2001) bankruptcy model enter significantly and with the expected sign. As we broaden the definition of financial distress to failure, and as we include more recent data, the effects of market capitalization and volatility become stronger, while the effects of losses, leverage, and recent past returns become slightly weaker.

In columns 4, 5, and 6 we report results for an alternative model that modifies the Shumway specification in several ways. First, we replace the traditional accounting 
ratios NITA and TLTA that use the book value of assets, with our ratios NIMTA and TLMTA that use the market value of assets. These measures are more sensitive to new information about firm prospects since equity values are measured using monthly market data rather than quarterly accounting data.

Second, we add lagged information about profitability and excess stock returns. One might expect that a long history of losses or a sustained decline in stock market value would be a better predictor of bankruptcy than one large quarterly loss or a sudden stock price decline in a single month. Exploratory regressions with lagged values confirm that lags of NIMTA and EXRET enter significantly, while lags of the other variables do not. As a reasonable summary, we impose geometrically declining weights on these lags. We construct

$$
\begin{aligned}
\text { NIMTAAVG } G_{t-1, t-12} & =\frac{1-\phi^{3}}{1-\phi^{12}}\left(\operatorname{NIMT}_{t-1, t-3}+\ldots+\phi^{9} \operatorname{NIMT} A_{t-9, t-12}\right) \\
\operatorname{EXRETAVG} G_{t-1, t-12} & =\frac{1-\phi}{1-\phi^{12}}\left(\operatorname{EXRET}_{t-1}+\ldots+\phi^{11} \operatorname{EXRET}_{t-12}\right),
\end{aligned}
$$

where the coefficient $\phi=2^{-\frac{1}{3}}$, implying that the weight is halved each quarter. When lagged excess returns or profitability are missing, we replace them with their cross-sectional means in order to avoid losing observations. The data suggest that this parsimonious specification captures almost all the predictability obtainable from lagged profitability and stock returns.

Third, we add the ratio of cash and short-term investments to the market value of total assets, CASHMTA, in order to capture the liquidity position of the firm. A firm with a high CASHMTA ratio has liquid assets available to make interest payments, and thus may be able to postpone bankruptcy with the possibility of avoiding it altogether if circumstances improve.

Fourth, the market to book ratio, MB, captures the relative value placed on the firm's equity by stockholders and by accountants. Our profitability and leverage ratios use market value; if book value is also relevant, then MB may enter the regression as a correction factor, increasing the probability of bankruptcy when market value is unusually high relative to book value. ${ }^{6}$

\footnotetext{
${ }^{6}$ Chacko, Hecht, and Hilscher (2004) discuss the measurement of credit risk when the market-tobook ratio is influenced both by cash flow expectations and discount rates.
} 
Finally, we add the log price per share of the firm, PRICE. We expect this variable to be relevant for low prices per share, particularly since both the NYSE and the Nasdaq have a minimum price per share of $\$ 1$ and commonly delist stocks that fail to meet this minimum (Macey, O'Hara, and Pompilio 2004). Reverse stock splits are sometimes used to keep stock prices away from the $\$ 1$ minimum level, but these often have negative effects on returns and therefore on market capitalization, suggesting that investors interpret reverse stock splits as a negative signal about company prospects (Woolridge and Chambers 1983, Hwang 1995). Exploratory analysis suggested that price per share is relevant below $\$ 15$, and so we truncate price per share at this level before taking the log.

All the new variables in our model enter the logit regression with the expected sign and are highly statistically significant. After accounting for differences in the scaling of the variables, there is little effect on the coefficients of the variables already included in the Shumway model, with the important exception of market capitalization. This variable is strongly correlated with log price per share; once price per share is included, market capitalization enters with a weak positive coefficient, probably as an ad hoc correction to the negative effect of price per share.

To get some idea of the relative impact of changes in the different variables, we compute the proportional impact on the failure probability of a one-standarddeviation increase in each predictor variable for a firm that initially has sample mean values of the predictor variables. Such an increase in profitability reduces the probability of failure by $44 \%$ of its initial value; the corresponding effects are a $156 \%$ increase for leverage, a $28 \%$ reduction for past excess return, a $64 \%$ increase for volatility, a $17 \%$ increase for market capitalization, a $21 \%$ reduction for cash holdings, a $9 \%$ increase for the market-book ratio, and a $56 \%$ reduction for price per share. Thus variations in leverage, volatility, price per share, and profitability are more important for failure risk than movements in market capitalization, cash, or the market-book ratio. These magnitudes roughly line up with the $t$ statistics reported in Table 3 .

Our proposed model delivers a noticeable improvement in explanatory power over the Shumway model. We report McFadden's pseudo $R^{2}$ coefficient for each specification, calculated as $1-L_{1} / L_{0}$, where $L_{1}$ is the log likelihood of the estimated model and $L_{0}$ is the log likelihood of a null model that includes only a constant term. The pseudo $R^{2}$ coefficient increases from 0.26 to 0.30 in predicting bankruptcies or failures over 1963-1998, and from 0.27 to 0.31 in predicting failures over 1963-2003. 


\subsection{Forecasting at long horizons}

At the one month horizon our best specification captures about $30 \%$ of the variation in bankruptcy risk. We now ask what happens as we try to predict bankruptcies further into the future. In Table 4 we estimate the conditional probability of bankruptcy in six months, one, two and three years. We again assume a logit specification but allow the coefficients on the variables to vary with the horizon of the prediction. In particular we assume that the probability of bankruptcy in $j$ months, conditional on survival in the dataset for $j-1$ months, is given by

$$
P_{t-1}\left(Y_{i, t-1+j}=1 \mid Y_{i, t-2+j}=0\right)=\frac{1}{1+\exp \left(-\alpha_{j}-\beta_{j} x_{i, t-1}\right)} .
$$

Note that this assumption does not imply a cumulative probability of bankruptcy that is logit. If the probability of bankruptcy in $j$ months did not change with the horizon $j$, that is if $\alpha_{j}=\alpha$ and $\beta_{j}=\beta$, and if firms exited the dataset only through bankruptcy, then the cumulative probability of bankruptcy over the next $j$ periods would be given by $1-\left(\exp \left(-\alpha-\beta x_{i}\right) /\left(1+\exp \left(-\alpha-\beta x_{i}\right)\right)^{j}\right.$, which no longer has the logit form. Variation in the parameters with the horizon $j$, and exit from the dataset through mergers and acquisitions, only make this problem worse. In principle we could compute the cumulative probability of bankruptcy by estimating models for each horizon $j$ and integrating appropriately; or by using our one-period model and making auxiliary assumptions about the time-series evolution of the predictor variables in the manner of Duffie and Wang (2003). We do not pursue these possibilities here, concentrating instead on the conditional probabilities of default at particular dates in the future.

As the horizon increases in Table 4, the coefficients, significance levels, and overall fit of the logit regression decline as one would expect. Even at three years, however, almost all the variables remain statistically significant.

Three predictor variables are particularly important at long horizons. The coefficient and $t$ statistic on volatility SIGMA are almost unchanged as the horizon increases; the coefficient and $t$ statistic on the market-to-book ratio MB increase with the horizon; and the coefficient on relative market capitalization RSIZE switches sign, becoming increasingly significant with the expected negative sign as the horizon increases. These variables, market capitalization, market-to-book ratio, and volatility, are persistent attributes of a firm that become increasingly important measures of 
financial distress at long horizons. Log price per share also switches sign, presumably as a result of the previously noted correlation between this variable and market capitalization.

Leverage and past excess stock returns have coefficients that decay particularly rapidly with the horizon, suggesting that these are primarily short-term signals of financial distress. Profitability and cash holdings are intermediate, with effects that decay more slowly.

In Table 4 the number of observations and number of failures vary with the horizon, because increasing the horizon forces us to drop observations at both the beginning and end of the dataset. Failures that occur within the first $j$ months of the sample cannot be related to the condition of the firm $j$ months previously, and the last $j$ months of the sample cannot be used to predict failures that may occur after the end of the sample. Also, many firms exit the dataset for other reasons between dates $t-1$ and $t-1+j$. On the other hand, as we lengthen the horizon we can include failures that are immediately preceded by missing data. We have run the same regressions for a subset of firms for which data are available at all the different horizons. This allows us to compare $R^{2}$ statistics directly across horizons. We obtain very similar results to those reported in Table 4, suggesting that variation in the available data is not responsible for our findings.

\subsection{Comparison with distance to default}

A leading alternative to the reduced-form econometric approach we have implemented in this paper is the structural approach of Moody's KMV (Crosbie and Bohn 2001), based on the structural default model of Merton (1974). This approach uses the Merton model to construct "distance to default", DD, a measure of the difference between the asset value of the firm and the face value of its debt, scaled by the standard deviation of the firm's asset value. Taken literally, the Merton model implies a deterministic relationship between DD and the probability of default, but in practice this relationship is estimated by a nonparametric regression of a bankruptcy or failure indicator on DD. That is, the historical frequency of bankruptcy is calculated for firms with different levels of DD, and this historical frequency is used as an estimate of the probability of bankruptcy going forward.

To implement the structural approach, we calculate DD in the manner of Hil- 
legeist, Keating, Cram, and Lunstedt (2004) by solving a system of two nonlinear equations. The details of the calculation are described in the Appendix. Table 5 compares the predictive power of the structural model with that of our best reducedform model. The top panel reports the coefficients on DD in a simple regression of our failure indicator on DD, and in a multiple regression on DD and the variables included in our reduced-form model. DD enters with the expected negative sign and is highly significant in the simple regression. In the multiple regression, however, it enters with a perverse positive sign at a short horizon, presumably because the reduced-form model already includes volatility and leverage, which are the two main inputs to the calculation of DD. The coefficient on DD only becomes negative and significant when the horizon is extended to one or three years.

The bottom panel of Table 5 reports the pseudo $R^{2}$ statistics for these regressions. While the structural model achieves a respectable $R^{2}$ of $16 \%$ for short-term failure prediction, our reduced-form model almost doubles this number. Adding DD to the reduced-form model has very little effect on the $R^{2}$, which is to be expected given the presence of volatility and leverage in the reduced-form model. These results hold both when we calculate $R^{2}$ in-sample, using coefficients estimated over the entire period 1963-2003, and when we calculate it out-of-sample, using coefficients each year from 1981 onwards that were estimated over the period up to but not including that year. The two sets of $R^{2}$ are very similar because most failures occur towards the end of the dataset, when the full-sample model and the rolling model have very similar coefficients.

The structural approach is designed to forecast default at a horizon of one year. This suggests that it might perform relatively better as we forecast failure further into the future. It is true that DD enters our model significantly with the correct sign at longer horizons, but Table 5 shows that the relative performance of DD and our econometric model is relatively constant across forecast horizons.

We conclude that the structural approach captures important aspects of the process determining corporate failure. The predictive power of DD is quite impressive given the tight restrictions on functional form imposed by the Merton model. If one's goal is to predict failures, however, it is clearly better to use a reduced-form econometric approach that allows volatility and leverage to enter with free coefficients and that includes other relevant variables. Bharath and Shumway (2004), in independent recent work, reach a similar conclusion. 


\subsection{Other time-series and cross-sectional effects}

As we noted in our discussion of Table 1, there is considerable variation in the failure rate over time. We now ask how well our model fits this pattern. We first calculate the fitted probability of failure for each company in our dataset using the coefficients from our best reduced-form model. We then average over all the predicted probabilities to obtain a prediction of the aggregate failure rate among companies with data available for failure prediction.

Figure 1 shows annual averages of predicted and realized failures, expressed as a fraction of the companies with available data. ${ }^{7}$ Our model captures much of the broad variation in corporate failures over time, including the strong and long-lasting increase in the 1980's and cyclical spikes in the early 1990's and early 2000's. However it somewhat overpredicts failures in 1974-5, underpredicts for much of the 1980's, and then overpredicts in the early 1990's.

We have explored the possibility that there are industry effects on bankruptcy and failure risk. The Shumway (2001) and Chava-Jarrow (2004) specification appears to behave somewhat differently in the finance, insurance, and real estate (FIRE) sector. That sector has a lower intercept and a more negative coefficient on profitability. However there is no strong evidence of sector effects in our best model, which relies more heavily on equity market data.

We have also used market capitalization and leverage as interaction variables, to test the hypotheses that other explanatory variables enter differently for small or highly indebted firms than for other firms. We have found no clear evidence that such interactions are important.

\footnotetext{
${ }^{7}$ The realized failure rate among these companies is slightly different from the failure rate reported in Table 1, which includes all failures and all active companies, not just those with data available for failure prediction.
} 


\section{Risks and average returns on distressed stocks}

We now turn our attention to the asset pricing implications of our failure model. Recent work on the distress premium has tended to use either traditional risk indices such as the Altman Z-score or Ohlson O-score (Dichev 1998, Griffin and Lemmon 2002, Ferguson and Shockley 2003) or the distance to default measure of KMV (Vassalou and Xing 2004, Da and Gao 2004). To the extent that our reduced-form model more accurately measures the risk of failure at short and long horizons, we can more accurately measure the premium that investors receive for holding distressed stocks.

Before presenting the results, we ask what results we should expect to find. On the one hand, if investors accurately perceive the risk of failure they may demand a premium for bearing it. The frequency of failure shows strong variation over time, as illustrated in Figure 1; even though much of this time-variation is explained by timevariation in our firm-level predictive variables, it still generates common movement in stock returns that might command a premium.

Of course, a risk can be pervasive and still be unpriced. If the standard implementation of the CAPM is exactly correct, for example, then each firm's risk is fully captured by its covariation with the market portfolio of equities, and distress risk is unpriced to the extent that it is uncorrelated with that portfolio. However it seems plausible that corporate failures may be correlated with declines in unmeasured components of wealth such as human capital (Fama and French 1996) or debt securities (Ferguson and Shockley 2003), in which case distress risk will carry a positive risk premium. ${ }^{8}$ This expectation is consistent with the high failure risk of small firms that have depressed market values, since small value stocks are well known to deliver high average returns.

\footnotetext{
${ }^{8}$ Fama and French (1996) state the idea particularly clearly: "Why is relative distress a state variable of special hedging concern to investors? One possible explanation is linked to human capital, an important asset for most investors. Consider an investor with specialized human capital tied to a growth firm (or industry or technology). A negative shock to the firm's prospects probably does not reduce the value of the investor's human capital; it may just mean that employment in the firm will grow less rapidly. In contrast, a negative shock to a distressed firm more likely implies a negative shock to the value of human capital since employment in the firm is more likely to contract. Thus, workers with specialized human capital in distressed firms have an incentive to avoid holding their firms' stocks. If variation in distress is correlated across firms, workers in distressed firms have an incentive to avoid the stocks of all distressed firms. The result can be a state-variable risk premium in the expected returns of distressed stocks." (p.77).
} 
An alternative possibility is that investors have not understood the relation between our predictive variables and failure risk, and so have not discounted the prices of high-risk stocks enough to offset their failure probability. In this case we will find that failure risk appears to command a negative risk premium during our sample period. This expectation is consistent with the high failure risk of volatile stocks, since Ang, Hodrick, Xing, and Zhang (2005) have recently found negative average returns for stocks with high idiosyncratic volatility.

We measure the premium for financial distress by sorting stocks according to their failure probabilities, estimated using the 12-month-ahead model of Table 4 . Each January from 1981 through 2003, the model is reestimated using only historically available data to eliminate look-ahead bias. We then form ten value-weighted portfolios of stocks that fall in different regions of the failure risk distribution. We minimize turnover costs and the effects of bid-ask bounce by eliminating stocks with prices less than $\$ 1$ at the portfolio construction date, and by holding the portfolios for a year, allowing the weights to drift with returns within the year rather than rebalancing monthly in response to updated failure probabilities. ${ }^{9}$ Our portfolios contain stocks in percentiles $0-5,5-10,10-20,20-40,40-60,60-80,80-90,90-95,95-99$, and 99-100 of the failure risk distribution. This portfolio construction procedure pays greater attention to the tails of the distribution, where the distress premium is likely to be more relevant, and particularly to the most distressed firms. We also construct long-short portfolios that go long the $10 \%$ or $20 \%$ of stocks with the lowest failure risk, and short the $10 \%$ or $20 \%$ of stocks with the highest failure risk.

Because we are studying the returns to distressed stocks, it is important to handle carefully the returns to stocks that are delisted and thus disappear from the CRSP database. In many cases CRSP reports a delisting return for the final month of the firm's life; we have 6,481 such delisting returns in our sample and we use them where they are available. Otherwise, we use the last available full-month return in CRSP. In some cases this effectively assumes that our portfolios sell distressed stocks at the end of the month before delisting, which imparts an upward bias to the returns on distressed-stock portfolios (Shumway 1997, Shumway and Warther 1999). ${ }^{10}$ We assume that the proceeds from sales of delisted stocks are reinvested in each portfolio in proportion to the weights of the remaining stocks in the portfolio. In a few cases,

\footnotetext{
${ }^{9}$ In the first version of this paper we calculated returns on portfolios rebalanced monthly, and obtained similar results to those reported here.

${ }^{10}$ In the first version of this paper we did not use CRSP delisting returns. The portfolio results were similar to those reported here.
} 
stocks are delisted and then re-enter the database, but we do not include these stocks in the sample after the first delisting. We treat firms that fail as equivalent to delisted firms, even if CRSP continues to report returns for these firms. That is, our portfolios sell stocks of companies that fail and we use the latest available CRSP data to calculate a final return on such stocks.

Table 6 reports the results. Each portfolio corresponds to one column of the table. Panel A reports average returns in excess of the market, in annualized percentage points, with $t$ statistics below in parentheses, and then alphas with respect to the CAPM, the three-factor model of Fama and French (1993), and a four-factor model proposed by Carhart (1997) that also includes a momentum factor. Panel B reports estimated factor loadings for excess returns on the three Fama-French factors, again with $t$ statistics. Panel $\mathrm{C}$ reports some relevant characteristics for the portfolios: the annualized standard deviation and skewness of each portfolio's excess return, the value-weighted mean standard deviation and skewness of the individual stock returns in each portfolio, and value-weighted means of RSIZE, market-book, and estimated failure probability for each portfolio. Figures 2 and 3 graphically summarize the behavior of factor loadings and alphas.

The average excess returns reported in the first row of Table 6 are strongly and almost monotonically declining in failure risk. The average excess returns for the lowest-risk $5 \%$ of stocks are positive at $3.4 \%$ per year, and the average excess returns for the highest-risk $1 \%$ of stocks are significantly negative at $-17.0 \%$ per year. A long-short portfolio holding the safest decile of stocks and shorting the most distressed decile has an average return of $10.0 \%$ per year and a standard deviation of $26 \%$, so its Sharpe ratio is comparable to that of the aggregate stock market.

There is striking variation in factor loadings across the portfolios in Table 6 . The low-failure-risk portfolios have negative market betas for their excess returns (that is, betas less than one for their raw returns), negative loadings on the value factor HML, and negative loadings on the small firm factor SMB. The high-failure-risk portfolios have positive market betas for their excess returns, positive loadings on HML, and extremely high loadings on SMB, reflecting the role of market capitalization in predicting bankruptcies at medium and long horizons.

These factor loadings imply that when we correct for risk using either the CAPM or the Fama-French three-factor model, we worsen the anomalous poor performance of distressed stocks rather than correcting it. A long-short portfolio that holds the safest decile of stocks and shorts the decile with the highest failure risk has an average 
excess return of $10.0 \%$ with a $t$ statistic of 1.9 ; it has a CAPM alpha of $12.4 \%$ with a $t$ statistic of 2.3; and it has a Fama-French three-factor alpha of $22.7 \%$ with a $t$ statistic of 6.1. When we use the Fama-French model to correct for risk, all portfolios beyond the 60th percentile of the failure risk distribution have statistically significant negative alphas.

One of the variables that predicts failure in our model is recent past return. This suggests that distressed stocks have negative momentum, which might explain their low average returns. To control for this, Table 6 also reports alphas from the Carhart (1997) four-factor model including a momentum factor. This adjustment cuts the alpha for the long-short decile portfolio roughly in half, from $22.7 \%$ to $12.0 \%$, but it remains strongly statistically significant.

Figure 4 illustrates the performance over time of the long-short portfolios that hold the safest decile (quintile) of stocks and short the most distressed decile (quintile). Performance is measured both by cumulative return, and by cumulative alpha or riskadjusted return from the Fama-French three-factor model. For comparison, we also plot the cumulative return on the market portfolio. Raw returns to these portfolios are concentrated in the late 1980's and late 1990's, with negative returns in the last few years; however the alphas for these portfolios are much more consistent over time.

The bottom panel of Table 6 reports characteristics of these portfolios. There is a wide spread in failure risk across the portfolios. Stocks in the safest $5 \%$ have an average failure probability of about 1 basis point, while stocks in the riskiest $5 \%$ have a failure probability of 34 basis points and the $1 \%$ of riskiest stocks have a failure probability of 80 basis points.

Stocks with a high risk of failure are highly volatile, with average standard deviations of almost $80 \%$ in the $5 \%$ most distressed stocks and $95 \%$ in the $1 \%$ most distressed stocks. This volatility does not fully diversify at the portfolio level. ${ }^{11}$ The excess return on the portfolio containing the $5 \%$ of stocks with the lowest failure risk has an annual standard deviation of $11 \%$, while the excess return for the portfolio containing the $5 \%$ of stocks with the highest failure risk has a standard deviation of $26 \%$, and the concentrated portfolio containing the $1 \%$ most distressed stocks has a

\footnotetext{
${ }^{11}$ On average there are slightly under 500 stocks for each $10 \%$ of the failure risk distribution, so purely idiosyncratic firm-level risk should diversify well, leaving portfolio risk to be determined primarily by common variation in distressed stock returns.
} 
standard deviation of almost 40\%. The returns on distressed stocks are also positively skewed, both at the portfolio level and particularly at the individual stock level.

Distressed stocks are much smaller than safe stocks. The value-weighted average size of the $5 \%$ safest stocks, reported in the table, is over 16 times larger than the value-weighted average size of the $5 \%$ most distressed stocks, and the equal-weighted size is about 9 times larger. Market-book ratios are high at both extremes of the failure risk distribution, and lower in the middle. This implies that distressed stocks have the market-book ratios of growth stocks, but the factor loadings of value stocks, since they load positively on the Fama-French value factor.

The wide spread in firm characteristics across the failure risk distribution suggests the possibility that the apparent underperformance of distressed stocks results from their characteristics rather than from financial distress per se. For example, it could be the case that extremely small stocks underperform in a manner that is not captured by the Fama-French three-factor model. To explore this possibility, in Table 7 we double-sort stocks, first on size using NYSE quintile breakpoints, and then on failure risk. In Table 8 we double-sort, first on the book-market ratio using NYSE quintile breakpoints, and then on failure risk.

Table 7 shows that distressed stocks underperform whether they are small stocks or large stocks. The underperformance is, however, considerably stronger among small stocks. The average return difference between the safest and most distressed quintiles is three times larger when the stocks are in the smallest quintile as opposed to the largest quintile. If we correct for risk using the Fama-French three-factor model, the alpha difference between the safest and most distressed quintiles is about $50 \%$ greater in the smallest quintile than in the largest quintile. The table also shows that in this sample period, there is only a weak size effect among safe stocks, and among distressed stocks large stocks outperform small stocks.

Table 8 shows that distressed stocks underperform whether they are growth stocks or value stocks. The raw underperformance is more extreme and statistically significant among growth stocks, but this difference disappears when we correct for risk using the Fama-French three-factor model. The value effect is absent in the safest stocks, similar to a result reported by Griffin and Lemmon (2002) using Ohlson's Oscore to proxy for financial distress. However this result may result from differences in three-factor loadings, as it largely disappears when we correct for risk using the three-factor model. 
As a final specification check, we have sorted stocks on our measure of distance to default. Contrary to the findings of Vassalou and Xing (2004), this sort also generates low returns for distressed stocks, particularly after correction for risk using the Fama-French three-factor model.

Overall, these results are discouraging for the view that distress risk is positively priced in the US stock market. We find that stocks with a high risk of failure have low average returns, despite their high loadings on small-cap and value risk factors. 


\section{Conclusion}

This paper makes two main contributions to the literature on financial distress. First, we carefully implement a reduced-form econometric model to predict corporate bankruptcies and failures at short and long horizons. Our best model has greater explanatory power than the existing state-of-the-art models estimated by Shumway (2001) and Chava and Jarrow (2004), and includes additional variables with sensible economic motivation. We believe that models of the sort estimated here have meaningful empirical advantages over the bankruptcy risk scores proposed by Altman (1968) and Ohlson (1980). While Altman's Z-score and Ohlson's O-score were seminal early contributions, better measures of bankruptcy risk are available today. We have also presented evidence that failure risk cannot be adequately summarized by a measure of distance to default inspired by Merton's (1974) pioneering structural model. While our distance to default measure is not exactly the same as those used by Crosbie and Bohn (2001) and Vassalou and Xing (2004), we believe that this result, similar to that reported independently by Bharath and Shumway (2004), is robust to alternative measures of distance to default.

Second, we show that stocks with a high risk of failure tend to deliver anomalously low average returns. We sort stocks by our 12-month-ahead estimate of failure risk, calculated from a model that uses only historically available data at each point in time. We calculate returns and risks on portfolios sorted by failure risk over the period 1981-2003. Distressed portfolios have low average returns, but high standard deviations, market betas, and loadings on Fama and French's (1993) small-cap and value risk factors. Thus, from the perspective of any of the leading empirical asset

pricing models, these stocks have negative alphas. This result is a significant challenge to the conjecture that the value and size effects are proxies for a financial distress premium. More generally, it is a challenge to standard models of rational asset pricing in which the structure of the economy is stable and well understood by investors.

Some previous authors have reported evidence that distressed stocks underperform the market, but results have varied with the measure of financial distress that is used. Our results are consistent with the findings of Dichev (1998), who uses Altman's Z-score and Ohlson's O-score to measure financial distress, and Garlappi, Shu, and Yan (2005), who obtain default risk measures from Moody's KMV. Vassalou and Xing (2004) calculate distance to default; they find some evidence that distressed stocks with a low distance to default have higher returns, but this evidence 
comes entirely from small value stocks. Da and Gao (2004) argue that Vassalou and Xing's distressed-stock returns are biased upwards by one-month reversal and bid-ask bounce. Griffin and Lemmon (2002), using O-score to measure distress, find that distressed growth stocks have particularly low returns. Our measure of financial distress generates underperformance among distressed stocks in all quintiles of the size and value distributions, but the underperformance is more dramatic among small stocks.

What can explain the anomalous underperformance of distressed stocks? Perhaps the most obvious explanation is that stock market investors underreact to negative information about company prospects. Hong, Lim, and Stein (2000) have argued that corporate managers have incentives to withhold bad news, which therefore reaches the market only gradually. Equity analysts can speed up the flow of information, but do so only for larger companies with better analyst coverage. To test whether this hypothesis explains the distress anomaly, one could ask whether the underperformance of distressed stocks is more extreme for companies with low analyst coverage. According to this view, the distress anomaly is related to the momentum effect and to the underperformance of companies with underfunded pension plans (Franzoni and Marin 2005).

Some investors may understand the poor average returns offered by distressed stocks, but hold them anyway. von Kalckreuth (2005) argues that majority owners of distressed companies can extract private benefits, for example by buying the company's output or assets at bargain prices. The incentive to extract such benefits is greater when the company is unlikely to survive and generate future profits for its shareholders. Thus majority owners may hold distressed stock, rather than selling it, because they earn a greater return than the return we measure to outside shareholders.

Barberis and Huang (2004) model the behavior of investors whose preferences satisfy the cumulative prospect theory of Tversky and Kahneman (1992). Such investors have a strong desire to hold positively skewed portfolios, and may even hold undiversified positions in positively skewed assets. Barberis and Huang argue that this effect can explain the high prices and low average returns on IPO's, whose returns are positively skewed. It is striking that both individual distressed stocks and our portfolios of distressed stocks also offer returns with strong positive skewness.

These hypotheses have the potential to explain why some investors hold distressed stocks despite their low average returns, but they do not explain why other rational 
investors fail to arbitrage the distress anomaly. Some distressed stocks may be unusually expensive or difficult to short, but more important limits to arbitrage are likely to be the reluctance of some investors to short stocks and the limited capital that arbitrageurs have available.

Finally, the distress anomaly may result from the preferences of institutional investors, together with a shift of assets from individuals to institutions during our sample period. Kovtunenko and Sosner (2003) have documented that institutions prefer to hold profitable stocks, and that this preference helped institutional performance during the 1980's and 1990's because profitable stocks outperformed the market. It is possible that the strong performance of profitable stocks in this period was endogenous, the result of increasing demand for these stocks by institutions. If institutions more generally prefer stocks with low failure risk, and tend to sell stocks that enter financial distress, then a similar mechanism could drive our results. This hypothesis implies that the underperformance of distressed stocks is a transitional and temporary phenomenon. It can be tested by relating the performance of distressed stocks over time to the changing institutional share of equity ownership and the characteristics of institutional portfolios. 


\section{Appendix}

In this appendix we discuss issues related to the construction of our dataset. All variables are constructed using COMPUSTAT and CRSP data. Relative size, excess return, and accounting ratios are defined as follows:

$$
\begin{aligned}
& R_{S I Z E_{i, t}}=\log \left(\frac{\text { Firm Market Equity }{ }_{i, t}}{\text { Total S\&P500 Market Value }}\right) \\
& E X R E T_{i, t}=\log \left(1+R_{i, t}\right)-\log \left(1+R_{S \& P 500, t}\right)
\end{aligned}
$$

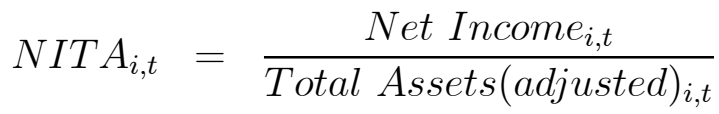

$$
\begin{aligned}
& \operatorname{TLTA}_{i, t}=\frac{\text { Total Liabilities }_{i, t}}{\text { Total Assets(adjusted })_{i, t}} \\
& \operatorname{NIMTA}_{i, t}=\frac{\text { Net }_{\text {Income }_{i, t}}}{\left(\text { Firm Market Equity }_{i, t}+\text { Total Liabilities }_{i, t}\right)} \\
& \operatorname{TLMTA}_{i, t}=\frac{\text { Total Liabilities }_{i, t}}{\left(\text { Firm Market Equity }_{i, t}+\text { Total Liabilities }_{i, t}\right)} \\
& C A S H M T A_{i, t}=\frac{\text { Cash and Short Term Investments }{ }_{i, t}}{\left(\text { Firm Market Equity }{ }_{i, t}+\text { Total Liabilities }_{i, t}\right)}
\end{aligned}
$$

The COMPUSTAT quarterly data items used are Data44 for total assets, Data69 for net income, and Data54 for total liabilities.

To deal with outliers in the data, we correct both NITA and TLTA using the difference between book equity (BE) and market equity (ME) to adjust the value of total assets:

$$
\text { Total Assets }(\text { adjusted })_{i, t}=T A_{i, t}+0.1 *\left(B E_{i, t}-M E_{i, t}\right)
$$

Book equity is as defined in Davis, Fama and French (2000) and outlined in detail in Cohen, Polk and Vuolteenaho (2003). This transformation helps with the values of total assets that are very small, probably mismeasured and lead to very large values of NITA. After total assets are adjusted, each of the seven explanatory variables is winsorized using a 5/95 percentile interval in order to eliminate outliers.

To measure the volatility of a firm's stock returns, we use a proxy, centered around zero rather than the rolling three-month mean, for daily variation of returns computed 
as an annualized three-month rolling sample standard deviation:

$$
S I G M A_{i, t-1, t-3}=\left(252 * \frac{1}{N-1} \sum_{k \in\{t-1, t-2, t-3\}} r_{i, k}^{2}\right)^{\frac{1}{2}}
$$

To eliminate cases where few observations are available, SIGMA is coded as missing if there are fewer than five non-zero observations over the three months used in the rolling-window computation. In calculating summary statistics and estimating regressions, we replace missing SIGMA observations with the cross-sectional mean of SIGMA; this helps us avoid losing some failure observations for infrequently traded companies. A dummy for missing SIGMA does not enter our regressions significantly. We use a similar procedure for missing lags of NIMTA and EXRET in constructing the moving average variables NIMTAAVG and EXRETAVG.

In order to calculate distance to default we need to estimate asset value and asset volatility, neither of which are directly observable. We construct measures of these variables by solving two equations simultaneously.

First, in the Merton model equity is valued as a European call option on the value of the firm's assets. Then:

$$
\begin{aligned}
M E & =T A_{D D} N\left(d_{1}\right)-B D \exp \left(-R_{B I L L} T\right) N\left(d_{2}\right) \\
d_{1} & =\frac{\log \left(\frac{T A_{D D}}{B D}\right)+\left(R_{B I L L}+\frac{1}{2} S I G M A_{D D}^{2}\right) T}{S I G M A_{D D} \sqrt{T}} \\
d_{2} & =d_{1}-S I G M A_{D D} \sqrt{T},
\end{aligned}
$$

where $T A_{D D}$ is the value of assets, $S I G M A_{D D}$ is the volatility of assets, $M E$ is the value of equity, and $B D$ is the face value of debt maturing at time $T$. Following convention in the literature on the Merton model (Crosbie and Bohn 2001, Vassalou and Xing 2004), we assume $T=1$, and use short term plus one half long term book debt to proxy for the face value of debt $B D$. This convention is a simple way to take account of the fact that long-term debt may not mature until after the horizon of the distance to default calculation. We measure the risk free rate $R_{B I L L}$ as the Treasury bill rate.

The second equation is a relation between the volatility of equity and the volatility of assets, often referred to as the optimal hedge equation:

$$
S I G M A=N\left(d_{1}\right) \frac{T A_{D D}}{M E} S I G M A_{D D}
$$


As starting values for asset value and asset volatility, we use $T A_{D D}=M E+B D$, and $S I G M A_{D D}=S I G M A(M E /(M E+B D)) .{ }^{12}$ We iterate until we have found values for $T A_{D D}$ and $S I G M A_{D D}$ that are consistent with the observed values of $M E, B D$, and $S I G M A$.

Finally, we compute distance to default as

$$
D D=\frac{-\log \left(B D / T A_{D D}\right)+0.06+R_{B I L L}-\frac{1}{2} S I G M A_{D D}^{2}}{S I G M A_{D D}} .
$$

The number 0.06 appears in the formula as an empirical proxy for the equity premium. Vassalou and Xing (2004) instead estimate the average return on each stock, while Hillegeist, Keating, Cram, and Lunstedt (2004) calculate the drift as the return on assets during the previous year. If the estimated expected return is negative, they replace it with the riskfree interest rate. We believe that it is better to use a common expected return for all stocks than a noisily estimated stock-specific number.

\footnotetext{
${ }^{12}$ If $B D$ is missing, we use $B D=$ median $(B D / T L) * T L$, where the median is calculated for the entire data set. This captures the fact that empirically, $B D$ tends to be much smaller than $T L$. If $B D=0$, we use $B D=$ median $(B D / T L) * T L$, where now we calculate the median only for small but nonzero values of $B D(0<B D<0.01)$. If $S I G M A$ is missing, we replace it with its cross sectional mean. Before calculating asset value and volatility, we adjust $B D$ so that $B D /(M E+B D)$ is winsorized at the $0.5 \%$ level. We also winsorize SIGMA at the $0.5 \%$ level. This significantly reduces instances in which the search algorithm does not converge.
} 


\section{References}

Altman, Edward I., 1968, Financial ratios, discriminant analysis and the prediction of corporate bankruptcy, Journal of Finance 23, 589-609.

Ang, Andrew, Robert J. Hodrick, Yuhang Xing, and Xiaoyan Zhang, 2005, The cross-section of volatility and expected returns, forthcoming Journal of Finance.

Asquith, Paul, Robert Gertner, and David Scharfstein, 1994, Anatomy of financial distress: An examination of junk-bond issuers, Quarterly Journal of Economics 109, 625-658.

Barberis, Nicholas and Ming Huang, 2004, Stocks as lotteries: The implications of probability weighting for security prices, unpublished paper, Yale University and Stanford University.

Bernanke, Ben S. and John Y. Campbell, 1988, Is there a corporate debt crisis?, Brookings Papers on Economic Activity 1, 83-139.

Bharath, Sreedhar and Tyler Shumway, 2004, Forecasting default with the KMVMerton model, unpublished paper, University of Michigan.

Burgstahler, D.C. and I.D. Dichev, 1997, Earnings management to avoid earnings decreases and losses, Journal of Accounting and Economics 24, 99-126.

Campbell, John Y., Martin Lettau, Burton Malkiel, and Yexiao Xu, 2001, Have individual stocks become more volatile? An empirical exploration of idiosyncratic risk, Journal of Finance 56, 1-43.

Carhart, Mark, 1997, On persistence in mutual fund performance, Journal of Finance 52, 57-82.

Chacko, George, Peter Hecht, and Jens Hilscher, 2004, Time varying expected returns, stochastic dividend yields, and default probabilities, unpublished paper, Harvard Business School.

Chan, K.C. and Nai-fu Chen, 1991, Structural and return characteristics of small and large firms, Journal of Finance 46, 1467-1484.

Chava, Sudheer and Robert A. Jarrow, 2004, Bankruptcy prediction with industry effects, Review of Finance 8, 537-569. 
Cohen, Randolph B., Christopher Polk and Tuomo Vuolteenaho, 2003, The value spread, Journal of Finance 58, 609-641.

Crosbie, Peter J. and Jeffrey R. Bohn, 2001, Modeling Default Risk, KMV, LLC, San Francisco, CA.

Da, Zhi and Pengjie Gao, 2004, Default risk and equity return: macro effect or micro noise?, unpublished paper, Northwestern University.

Davis, James L., Eugene F. Fama and Kenneth R. French, 2000, Characteristics, covariances, and average returns: 1929 to 1997, Journal of Finance 55, 389406.

Dechow, Patricia M., Scott A. Richardson, and Irem Tuna, 2003, Why are earnings kinky? An examination of the earnings management explanation, Review of Accounting Studies 8, 355-384.

Dichev, Ilia, 1998, Is the risk of bankruptcy a systematic risk?, Journal of Finance $53,1141-1148$.

Duffie, Darrell, and Ke Wang, 2004, Multi-period corporate failure prediction with stochastic covariates, NBER Working Paper No. 10743.

Fama, Eugene F. and Kenneth R. French, 1993, Common risk factors in the returns on stocks and bonds, Journal of Financial Economics 33, 3-56.

Fama, Eugene F. and Kenneth R. French, 1996, Multifactor explanations of asset pricing anomalies, Journal of Finance 51, 55-84.

Ferguson, Michael F. and Richard L. Shockley, 2003, Equilibrium "anomalies", Journal of Finance 58, 2549-2580.

Franzoni, Francesco and Jose M. Marin, 2005, Pension plan funding and stock market efficiency, forthcoming Journal of Finance.

Garlappi, Lorenzo, Tao Shu, and Hong Yan, 2005, Default risk and stock returns, unpublished paper, University of Texas at Austin.

Gilson, Stuart C., Kose John, and Larry Lang, 1990, Troubled debt restructurings: An empirical study of private reorganization of firms in default, Journal of Financial Economics 27, 315-353. 
Gilson, Stuart C., 1997, Transactions costs and capital structure choice: Evidence from financially distressed firms, Journal of Finance 52, 161-196.

Griffin, John M. and Michael L. Lemmon, 2002, Book-to-market equity, distress risk, and stock returns, Journal of Finance 57, 2317-2336.

Hayn, C., 1995, The information content of losses, Journal of Accounting and Economics 20, 125-153.

Hwang, C.Y., 1995, Microstructure and reverse splits, Review of Quantitative Finance and Accounting 5, 169-177.

Hillegeist, Stephen A., Elizabeth Keating, Donald P. Cram and Kyle G. Lunstedt, 2004, Assessing the probability of bankruptcy, Review of Accounting Studies 9, $5-34$.

Hong, Harrison, Terence Lim, and Jeremy C. Stein, 2000, Bad news travels slowly: Size, analyst coverage, and the profitability of momentum strategies, Journal of Finance 55, 265-295.

Kovtunenko, Boris and Nathan Sosner, 2003, Sources of institutional performance, unpublished paper, Harvard University.

Macey, Jonathan, Maureen O'Hara, and David Pompilio, 2004, Down and out in the stock market: the law and finance of the delisting process, unpublished paper, Yale University and Cornell University.

Merton, Robert C., 1974, On the pricing of corporate debt: the risk structure of interest rates, Journal of Finance 29, 449-470.

Mossman, Charles E., Geoffrey G. Bell, L. Mick Swartz, and Harry Turtle, 1998, An empirical comparison of bankruptcy models, Financial Review 33, 35-54.

Ohlson, James A., 1980, Financial ratios and the probabilistic prediction of bankruptcy, Journal of Accounting Research 18, 109-131.

Opler, Tim and Sheridan Titman, 1994, Financial distress and corporate performance, Journal of Finance 49, 1015-1040.

Shumway, Tyler, 1997, The delisting bias in CRSP data, Journal of Finance 52, $327-340$. 
Shumway, Tyler, 2001, Forecasting bankruptcy more accurately: a simple hazard model, Journal of Business 74, 101-124.

Shumway, Tyler and Vincent A. Warther, 1999, The delisting bias in CRSP's Nasdaq data and its implications for the size effect, Journal of Finance 54, 2361-2379.

Tashjian, Elizabeth, Ronald Lease, and John McConnell, 1996, Prepacks: An empirical analysis of prepackaged bankruptcies, Journal of Financial Economics $40,135-162$.

Tversky, Amos and Daniel Kahneman, 1992, Advances in prospect theory: Cumulative representation of uncertainty, Journal of Risk and Uncertainty 5, 297-323.

Vassalou, Maria and Yuhang Xing, 2004, Default risk in equity returns, Journal of Finance 59, 831-868.

von Kalckreuth, Ulf, 2005, A 'wreckers theory' of financial distress, Deutsche Bundesbank discussion paper.

Woolridge, J.R. and D.R. Chambers, 1983, Reverse splits and shareholder wealth, Financial Management 5-15.

Zmijewski, Mark E., 1984, Methodological issues related to the estimation of financial distress prediction models, Journal of Accounting Research 22, 59-82. 
Table 1: Number of bankruptcies and failures per year

The table lists the total number of active firms (Column 1), total number of bankruptcies (Column 2) and failures (Column 4) for every year of our sample period. The number of active firms is computed by averaging over the numbers of active firms across all months of the year.

$\begin{array}{lccccc}\text { Year } & \text { Active Firms } & \text { Bankruptcy } & \mathbf{( \% )} & \text { Failure } & \mathbf{( \% )} \\ 1963 & 1281 & 0 & 0.00 & 0 & 0.00 \\ 1964 & 1357 & 2 & 0.15 & 2 & 0.15 \\ 1965 & 1436 & 2 & 0.14 & 2 & 0.14 \\ 1966 & 1513 & 1 & 0.07 & 1 & 0.07 \\ 1967 & 1598 & 0 & 0.00 & 0 & 0.00 \\ 1968 & 1723 & 0 & 0.00 & 0 & 0.00 \\ 1969 & 1885 & 0 & 0.00 & 0 & 0.00 \\ 1970 & 2067 & 5 & 0.24 & 5 & 0.24 \\ 1971 & 2199 & 4 & 0.18 & 4 & 0.18 \\ 1972 & 2650 & 8 & 0.30 & 8 & 0.30 \\ 1973 & 3964 & 6 & 0.15 & 6 & 0.15 \\ 1974 & 4002 & 18 & 0.45 & 18 & 0.45 \\ 1975 & 4038 & 5 & 0.12 & 5 & 0.12 \\ 1976 & 4101 & 14 & 0.34 & 14 & 0.34 \\ 1977 & 4157 & 12 & 0.29 & 12 & 0.29 \\ 1978 & 4183 & 14 & 0.33 & 15 & 0.36 \\ 1979 & 4222 & 14 & 0.33 & 14 & 0.33 \\ 1980 & 4342 & 26 & 0.60 & 26 & 0.60 \\ 1981 & 4743 & 23 & 0.48 & 23 & 0.48 \\ 1982 & 4995 & 29 & 0.58 & 29 & 0.58 \\ 1983 & 5380 & 50 & 0.93 & 50 & 0.93 \\ 1984 & 5801 & 73 & 1.26 & 74 & 1.28 \\ 1985 & 5912 & 76 & 1.29 & 77 & 1.30 \\ 1986 & 6208 & 95 & 1.53 & 95 & 1.53 \\ 1987 & 6615 & 54 & 0.82 & 54 & 0.82 \\ 1988 & 6686 & 84 & 1.26 & 85 & 1.27 \\ 1989 & 6603 & 74 & 1.12 & 78 & 1.18 \\ 1990 & 6515 & 80 & 1.23 & 82 & 1.26 \\ 1991 & 6571 & 70 & 1.07 & 73 & 1.11 \\ 1992 & 6914 & 45 & 0.65 & 50 & 0.72 \\ 1993 & 7469 & 36 & 0.48 & 39 & 0.52 \\ 1994 & 8067 & 30 & 0.37 & 33 & 0.41 \\ 1995 & 8374 & 43 & 0.51 & 45 & 0.54 \\ 1996 & 8782 & 32 & 0.36 & 34 & 0.39 \\ 1997 & 9544 & 44 & 0.46 & 61 & 0.64 \\ 1998 & 9844 & 49 & 0.50 & 150 & 1.52 \\ 1999 & 9675 & . & . & 209 & 2.16 \\ 2000 & 9426 & . & . & 167 & 1.77 \\ 2001 & 8817 & . & . & 324 & 3.67 \\ 2002 & 8242 & . & . & 221 & 2.68 \\ 2003 & 7833 & . & . & 167 & 2.13\end{array}$



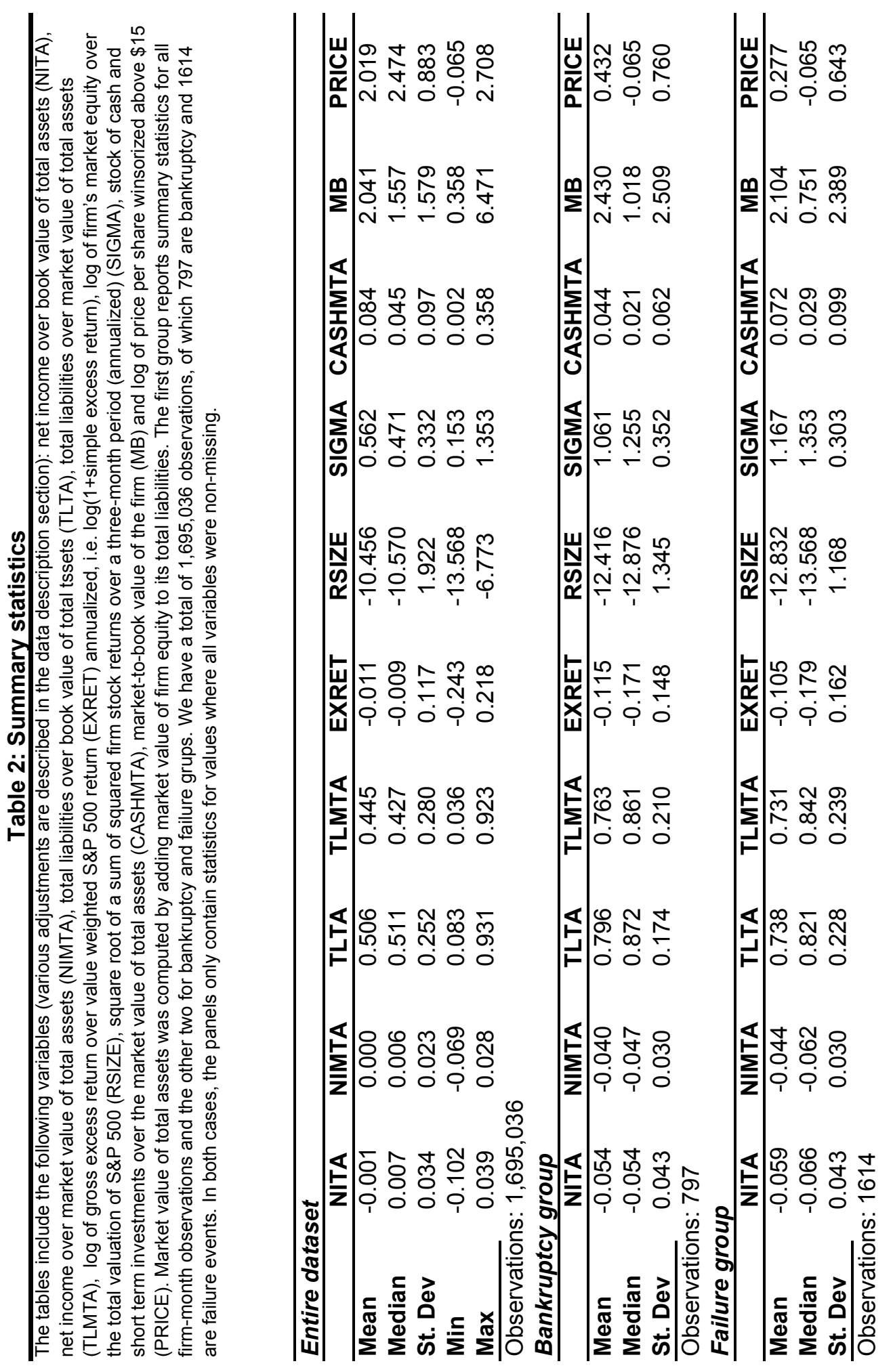
Table 3: Logit regressions on predictor variables

This table reports results from logit regressions of the bankruptcy and failure indicator on predictor variables. The value of the predictor variable is known at the beginning of the month over which bankruptcy is measured. Net income and total liabilities are scaled by accounting and market total assets.

\begin{tabular}{|c|c|c|c|c|c|c|}
\hline & $(1)$ & (2) & (3) & $(4)$ & $(5)$ & (6) \\
\hline Dep variable: & Bankruptcy & Failure & Failure & Bankruptcy & Failure & Failure \\
\hline Sample period: & 1963-1998 & 1963-1998 & $1963-2003$ & 1963-1998 & 1963-1998 & 1963-2003 \\
\hline NITA & $\begin{array}{c}-14.05 \\
(16.03)^{\star \star}\end{array}$ & $\begin{array}{c}-13.79 \\
(17.06)^{\star \star}\end{array}$ & $\begin{array}{c}-12.782 \\
(21.26)^{\star *}\end{array}$ & & & \\
\hline NIMTAAVG & & & & $\begin{array}{c}-32.518 \\
(17.65)^{\star *}\end{array}$ & $\begin{array}{c}-32.457 \\
(19.01)^{\star *}\end{array}$ & $\begin{array}{c}-29.672 \\
(23.37)^{\star *}\end{array}$ \\
\hline TLTA & $\begin{array}{c}5.378 \\
(25.91)^{\star *}\end{array}$ & $\begin{array}{c}4.62 \\
(26.28)^{\star *}\end{array}$ & $\begin{array}{c}3.744 \\
(32.32)^{\star *}\end{array}$ & & & \\
\hline TLMTA & & & & $\begin{array}{c}4.322 \\
(22.82)^{\star \star}\end{array}$ & $\begin{array}{c}3.865 \\
(23.39)^{\star \star}\end{array}$ & $\begin{array}{c}3.36 \\
(27.80)^{\star *}\end{array}$ \\
\hline EXRET & $\begin{array}{c}-3.297 \\
(12.12)^{\star \star}\end{array}$ & $\begin{array}{c}-2.903 \\
(11.81)^{\star \star}\end{array}$ & $\begin{array}{c}-2.319 \\
(13.57)^{\star \star}\end{array}$ & & & \\
\hline EXRETAVG & & & & $\begin{array}{c}-9.51 \\
(12.05)^{\star *}\end{array}$ & $\begin{array}{c}-8.819 \\
(12.08)^{\star \star}\end{array}$ & $\begin{array}{c}-7.35 \\
(14.03)^{\star *}\end{array}$ \\
\hline SIGMA & $\begin{array}{c}2.148 \\
(16.40)^{\star \star}\end{array}$ & $\begin{array}{c}2.28 \\
(18.34)^{\star *}\end{array}$ & $\begin{array}{c}2.763 \\
(26.63)^{\star *}\end{array}$ & $\begin{array}{c}0.92 \\
(6.66)^{\star *}\end{array}$ & $\begin{array}{c}1.15 \\
(8.79)^{\star \star}\end{array}$ & $\begin{array}{c}1.482 \\
(13.54)^{\star *}\end{array}$ \\
\hline RSIZE & $\begin{array}{c}-0.188 \\
(5.56)^{\star \star}\end{array}$ & $\begin{array}{c}-0.253 \\
(7.60)^{\star \star}\end{array}$ & $\begin{array}{c}-0.374 \\
(13.26)^{\star *}\end{array}$ & $\begin{array}{c}0.246 \\
(6.18)^{\star *}\end{array}$ & $\begin{array}{c}0.169 \\
(4.32)^{\star \star}\end{array}$ & $\begin{array}{c}0.082 \\
(2.62)^{\star *}\end{array}$ \\
\hline CASHMTA & & & & $\begin{array}{c}-4.888 \\
(7.96)^{\star *}\end{array}$ & $\begin{array}{c}-3.218 \\
(6.59)^{* *}\end{array}$ & $\begin{array}{c}-2.401 \\
(8.64)^{* *}\end{array}$ \\
\hline MB & & & & $\begin{array}{c}0.099 \\
(6.72)^{\star \star}\end{array}$ & $\begin{array}{c}0.095 \\
(6.76)^{\star \star}\end{array}$ & $\begin{array}{c}0.054 \\
(4.87)^{\star \star}\end{array}$ \\
\hline PRICE & & & & $\begin{array}{c}-0.882 \\
(10.39)^{\star *}\end{array}$ & $\begin{array}{c}-0.807 \\
(10.09)^{\star *}\end{array}$ & $\begin{array}{c}-0.937 \\
(14.77)^{\star *}\end{array}$ \\
\hline Constant & $\begin{array}{c}-15.214 \\
(39.45)^{\star *}\end{array}$ & $\begin{array}{c}-15.41 \\
(40.87)^{\star *}\end{array}$ & $\begin{array}{c}-16.576 \\
(50.92)^{\star \star}\end{array}$ & $\begin{array}{c}-7.648 \\
(13.66)^{\star *}\end{array}$ & $\begin{array}{c}-8.45 \\
(15.63)^{\star *}\end{array}$ & $\begin{array}{c}-9.079 \\
(20.84)^{\star *}\end{array}$ \\
\hline Observations & 1282853 & 1302564 & 1695036 & 1282853 & 1302564 & 1695036 \\
\hline Failures & 797 & 911 & 1614 & 797 & 911 & 1614 \\
\hline Pseudo R sq & 0.260 & 0.258 & 0.270 & 0.299 & 0.296 & 0.312 \\
\hline
\end{tabular}


Table 4: Logit regressions on lagged variables

The table below takes our best-model variables and tests their predictive power as we lag them by 6,12 , 24 , and 36 months. The dependent variable is failure and the sample period is 1963-2003.

\begin{tabular}{|c|c|c|c|c|c|}
\hline & (1) & (2) & (3) & (4) & (5) \\
\hline Lag (months) & 0 & 6 & 12 & 24 & 36 \\
\hline NIMTAAVG & $\begin{array}{c}-29.672 \\
(23.37)^{\star \star}\end{array}$ & $\begin{array}{l}-23.915 \\
(21.82)^{\star *}\end{array}$ & $\begin{array}{c}-20.264 \\
(18.09)^{\star *}\end{array}$ & $\begin{array}{c}-13.232 \\
(10.50)^{\star *}\end{array}$ & $\begin{array}{l}-14.061 \\
(9.77)^{\star *}\end{array}$ \\
\hline TLMTA & $\begin{array}{c}3.36 \\
(27.80)^{\star *}\end{array}$ & $\begin{array}{c}2.057 \\
(22.63)^{\star *}\end{array}$ & $\begin{array}{c}1.416 \\
(16.23)^{\star *}\end{array}$ & $\begin{array}{c}0.917 \\
(9.85)^{\star *}\end{array}$ & $\begin{array}{c}0.643 \\
(6.25)^{\star *}\end{array}$ \\
\hline EXRETAVG & $\begin{array}{c}-7.35 \\
(14.03)^{\star *}\end{array}$ & $\begin{array}{c}-7.792 \\
(15.97)^{\star *}\end{array}$ & $\begin{array}{c}-7.129 \\
(14.15)^{\star *}\end{array}$ & $\begin{array}{c}-5.607 \\
(10.14)^{* *}\end{array}$ & $\begin{array}{c}-2.564 \\
(4.14)^{\star *}\end{array}$ \\
\hline SIGMA & $\begin{array}{c}1.482 \\
(13.54)^{\star \star}\end{array}$ & $\begin{array}{c}1.268 \\
(14.57)^{\star *}\end{array}$ & $\begin{array}{c}1.411 \\
(16.49)^{\star *}\end{array}$ & $\begin{array}{c}1.515 \\
(16.92)^{\star *}\end{array}$ & $\begin{array}{c}1.334 \\
(13.54)^{\star *}\end{array}$ \\
\hline RSIZE & $\begin{array}{c}0.082 \\
(2.62)^{\star *}\end{array}$ & $\begin{array}{c}0.047 \\
(2.02)^{\star}\end{array}$ & $\begin{array}{l}-0.045 \\
(2.09)^{*}\end{array}$ & $\begin{array}{c}-0.132 \\
(6.19)^{\star \star}\end{array}$ & $\begin{array}{c}-0.18 \\
(8.03)^{\star *}\end{array}$ \\
\hline CASHMTA & $\begin{array}{c}-2.401 \\
(8.64)^{\star \star}\end{array}$ & $\begin{array}{c}-2.397 \\
(9.77)^{\star \star}\end{array}$ & $\begin{array}{c}-2.132 \\
(8.53)^{\star \star}\end{array}$ & $\begin{array}{c}-1.37 \\
(5.09)^{\star *}\end{array}$ & $\begin{array}{c}-1.414 \\
(4.61)^{\star *}\end{array}$ \\
\hline MB & $\begin{array}{c}0.054 \\
(4.87)^{* *}\end{array}$ & $\begin{array}{c}0.047 \\
(4.22)^{* *}\end{array}$ & $\begin{array}{c}0.075 \\
(6.33)^{* *}\end{array}$ & $\begin{array}{c}0.108 \\
(7.92)^{\star *}\end{array}$ & $\begin{array}{c}0.125 \\
(8.17)^{\star *}\end{array}$ \\
\hline PRICE & $\begin{array}{c}-0.937 \\
(14.77)^{\star *}\end{array}$ & $\begin{array}{c}-0.468 \\
(10.36)^{\star *}\end{array}$ & $\begin{array}{l}-0.058 \\
(1.40)\end{array}$ & $\begin{array}{c}0.212 \\
(4.96)^{\star *}\end{array}$ & $\begin{array}{c}0.279 \\
(6.00)^{\star *}\end{array}$ \\
\hline Constant & $\begin{array}{c}-9.079 \\
(20.84)^{* *}\end{array}$ & $\begin{array}{c}-8.069 \\
(25.00)^{* *}\end{array}$ & $\begin{array}{c}-9.164 \\
(30.89)^{\star *}\end{array}$ & $\begin{array}{c}-10.233 \\
(34.48)^{\star *}\end{array}$ & $\begin{array}{l}-10.534 \\
(33.53)^{* *}\end{array}$ \\
\hline Observations & 1695036 & 1642006 & 1565634 & 1384951 & 1208610 \\
\hline Failures & 1614 & 2008 & 1968 & 1730 & 1467 \\
\hline Pseudo R sq & 0.312 & 0.188 & 0.114 & 0.061 & 0.044 \\
\hline
\end{tabular}

Absolute value of $z$ statistics in parentheses

${ }^{*}$ significant at $5 \%$; ** significant at $1 \%$ 


\section{Table 5: Distance to default and our best model}

In panel A we report the coefficients on distance to default variable in a logit regression by itself and included in our best model. The dependent variable is failure and the sample period is 1963-2003.

Regression results are reported for various horizons: 0,12 , and 36 months. Panel B reports the in-sample and out-of-sample pseudo-R squared for the regressions from panel $A$

Panel A - Coefficients

Lag (months)

DD only

DD in best model

\begin{tabular}{ccc}
$(1)$ & $(2)$ & $(3)$ \\
\hline 0 & 12 & 36 \\
\hline-0.883 & -0.345 & -0.165 \\
$(39.73)^{\star *}$ & $(33.73)^{\star *}$ & $(20.88)^{\star *}$ \\
0.048 & -0.091 & -0.09 \\
$(2.62)^{\star *}$ & $(7.52)^{\star *}$ & $(8.09)^{\star *}$ \\
1695036 & 1565634 & 1208610 \\
1614 & 1968 & 1467
\end{tabular}

Observations

Failures

1614

(1)

(2)

(3)

In-sample (1963 - 2003)

DD only

Best model

0.159

0.066

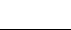

DD in Best model

0.312

0.066

0.026

0.312

0.114

0.044

Out-of-sample (1981 - 2003)

DD only

Best model

\begin{tabular}{lll}
0.312 & 0.117 & 0.045 \\
\hline & & \\
\hline 0.156 & 0.064 & 0.025 \\
0.310 & 0.108 & 0.039 \\
\hline
\end{tabular}




\section{Table 6: Returns on distressed stock portfolios}

We sorted all stocks based on the predicted 12-month probability of failure and divided them into 10 portfolios based on percentile cutoffs. For example, 0 to 5 th percentile (0005) and 99 th to 100th percentile (9900). In the table below we show results from regressions of excess returns over the market on a constant, market return (RM), as well as three (RM, HML, SMB) and four (RM, HML, SMB, UMD) FF factor regressions. Panel A shows monthly alphas (in annualized percent units) from these regressions and the corresponding t-stat below. Panel B shows loadings on the three factors, as well as corresponding t-stats below, from the 3-factor regression. Panel $\mathrm{C}$ reports annualized standard deviation and skewness of individual and portfolio returns, mean relative size (RSIZE), market-to-book (MB), and probability of failure (Phat) values for each portfolio.

Panel A - Portfolio alphas

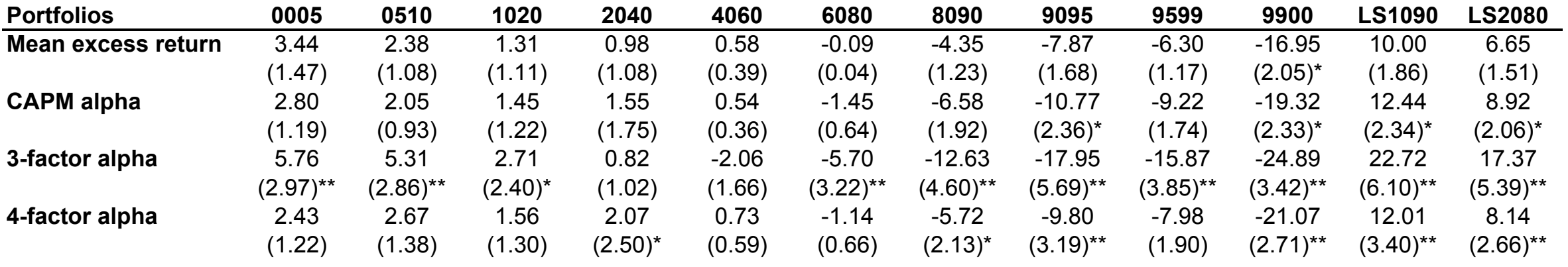

Panel B - 3-factor regression coefficients

\begin{tabular}{|c|c|c|c|c|c|c|c|c|c|c|c|c|}
\hline \multirow{3}{*}{$\begin{array}{l}\text { Portfolios } \\
\text { RM }\end{array}$} & 0005 & 0510 & 1020 & 2040 & 4060 & 6080 & 8090 & 9095 & 9599 & 9900 & LS1090 & LS2080 \\
\hline & -0.083 & -0.111 & -0.058 & -0.028 & 0.104 & 0.334 & 0.480 & 0.477 & 0.443 & 0.249 & -0.568 & -0.554 \\
\hline & $(2.21)^{*}$ & $(3.09)^{\star *}$ & $(2.64)^{* *}$ & (1.79) & $(4.34)^{\star *}$ & $(9.78)^{\star *}$ & $(9.05)^{\star *}$ & $(7.83)^{\star *}$ & $(5.56)^{\star *}$ & (1.77) & $(7.89)^{\star *}$ & $(8.90)^{\star *}$ \\
\hline HML & $\begin{array}{c}-0.474 \\
(9.67)^{\star *}\end{array}$ & $\begin{array}{c}-0.499 \\
(10.61)^{* *}\end{array}$ & $\begin{array}{c}-0.177 \\
(6.17)^{\star *}\end{array}$ & $\begin{array}{c}0.121 \\
(5.98)^{\star *}\end{array}$ & $\begin{array}{c}0.379 \\
(12.12)^{\star *}\end{array}$ & $\begin{array}{c}0.612 \\
(13.69)^{\star *}\end{array}$ & $\begin{array}{c}0.849 \\
(12.22)^{* *}\end{array}$ & $\begin{array}{c}0.916 \\
(11.49)^{* *}\end{array}$ & $\begin{array}{c}0.829 \\
(7.94)^{* *}\end{array}$ & $\begin{array}{c}0.612 \\
(3.33)^{* *}\end{array}$ & $\begin{array}{c}-1.394 \\
(14.79)^{\star *}\end{array}$ & $\begin{array}{c}-1.182 \\
(14.51)^{\star *}\end{array}$ \\
\hline SMB & $\begin{array}{c}0.212 \\
(3.89)^{* *}\end{array}$ & $\begin{array}{l}0.037 \\
(0.70)\end{array}$ & $\begin{array}{c}-0.118 \\
(3.69)^{\star *}\end{array}$ & $\begin{array}{c}-0.091 \\
(4.04)^{* *}\end{array}$ & $\begin{array}{c}0.121 \\
(3.49)^{\star *}\end{array}$ & $\begin{array}{c}0.262 \\
(5.27)^{\star *}\end{array}$ & $\begin{array}{c}0.590 \\
(7.64)^{\star *}\end{array}$ & $\begin{array}{c}1.466 \\
(16.52)^{\star *}\end{array}$ & $\begin{array}{c}1.535 \\
(13.23)^{\star *}\end{array}$ & $\begin{array}{c}1.973 \\
(9.63)^{* *}\end{array}$ & $\begin{array}{c}-1.394 \\
(13.30)^{* *}\end{array}$ & $\begin{array}{c}-0.833 \\
(9.19)^{\star *}\end{array}$ \\
\hline
\end{tabular}

Panel C - Portfolio characteristics

\begin{tabular}{|c|c|c|c|c|c|c|c|c|c|c|c|c|}
\hline Portfolios & 0005 & 0510 & 1020 & 2040 & 4060 & 6080 & 8090 & 9095 & 9599 & 9900 & LS1090 & LS2080 \\
\hline Portfolio SD & 0.112 & 0.105 & 0.057 & 0.044 & 0.071 & 0.111 & 0.169 & 0.225 & 0.258 & 0.396 & 0.258 & 0.211 \\
\hline Portfolio skewness & 1.105 & 0.327 & 0.419 & -0.265 & -0.137 & -0.278 & 1.038 & 1.746 & 2.371 & 1.832 & & \\
\hline Individual SD & 0.361 & 0.351 & 0.305 & 0.289 & 0.308 & 0.371 & 0.511 & 0.685 & 0.793 & 0.949 & & \\
\hline Individual skewness & 0.645 & 0.751 & 0.595 & 1.363 & 1.676 & 0.841 & 1.948 & 3.790 & 2.960 & 2.395 & & \\
\hline Mean RSIZE & -7.786 & -7.479 & -7.236 & -7.172 & -7.371 & -7.803 & -8.744 & -10.000 & -10.584 & -11.273 & & \\
\hline Mean MB & 2.648 & 3.089 & 2.945 & 2.499 & 2.117 & 1.989 & 2.256 & 2.611 & 3.114 & 3.783 & & \\
\hline Mean Phat & $0.011 \%$ & $0.014 \%$ & $0.018 \%$ & $0.024 \%$ & $0.036 \%$ & $0.057 \%$ & $0.11 \%$ & $0.19 \%$ & $0.34 \%$ & $0.80 \%$ & & \\
\hline
\end{tabular}




\section{Table 7: Double sorting on size and distress}

This table reports mean excess returns over the market and 3-factor alphas for portfolios sorted on size (ME) and fitted 12-month fitted probability of failure (Phat). We first sort stocks into size quintiles using NYSE breakpoints (following Fama-French) and then, within each quintile, sort stocks into predicted failure probability quintiles. All returns are in annualized percent units.

\begin{tabular}{|c|c|c|c|c|c|c|}
\hline \multicolumn{7}{|c|}{ Panel A - mean excess return } \\
\hline \multirow{2}{*}{$\begin{array}{l}\text { MEIPhat } \\
\text { Large }\end{array}$} & \multicolumn{4}{|c|}{ Low } & High & Low - High \\
\hline & 3.94 & -1.48 & -0.27 & 0.43 & 0.93 & 3.01 \\
\hline & $(2.02)^{*}$ & $(1.18)$ & $(0.18)$ & $(0.29)$ & $(0.41)$ & $(0.77)$ \\
\hline & 4.14 & 0.29 & 2.07 & 0.80 & 1.10 & 3.04 \\
\hline & $(2.03)^{*}$ & $(0.20)$ & $(1.42)$ & $(0.59)$ & $(0.43)$ & $(0.78)$ \\
\hline & 4.65 & 2.98 & -0.22 & 1.04 & 0.43 & 4.22 \\
\hline & $(2.01)^{*}$ & $(1.54)$ & $(0.15)$ & $(0.65)$ & $(0.17)$ & $(1.25)$ \\
\hline & 6.21 & 2.56 & 1.68 & 1.11 & -2.40 & 8.62 \\
\hline & $(2.51)^{*}$ & $(1.21)$ & $(0.80)$ & $(0.57)$ & $(0.86)$ & $(2.91)^{* *}$ \\
\hline Small & 3.77 & -0.30 & -3.38 & -5.96 & -10.62 & 10.87 \\
\hline & $(2.18)^{*}$ & $(1.27)$ & $(1.20)$ & $(0.29)$ & $(1.22)$ & $(3.07)^{\star *}$ \\
\hline Large - Small & $\begin{array}{l}-1.39 \\
(0.48) \\
\end{array}$ & $\begin{array}{l}-4.63 \\
(1.47) \\
\end{array}$ & $\begin{array}{l}-3.15 \\
(0.97) \\
\end{array}$ & $\begin{array}{l}-0.43 \\
(0.12) \\
\end{array}$ & $\begin{array}{c}6.47 \\
(1.33) \\
\end{array}$ & \\
\hline \multicolumn{7}{|c|}{ Panel B - 3-factor alpha } \\
\hline MEIPhat & Low & & & & High & Low - High \\
\hline \multirow[t]{8}{*}{ Large } & 7.51 & 0.30 & 0.39 & -1.58 & -4.08 & 11.59 \\
\hline & $(4.83)^{* *}$ & $(0.27)$ & $(0.35)$ & $(1.40)$ & $(2.42)^{*}$ & $(4.07)^{\star *}$ \\
\hline & 6.20 & 0.97 & 1.48 & -0.58 & -5.37 & 11.57 \\
\hline & $(3.96)^{\star *}$ & $(0.78)$ & (1.05) & $(0.48)$ & $(2.82)^{\star \star}$ & $(4.05)^{\star *}$ \\
\hline & 6.13 & 4.10 & -1.15 & -0.87 & -5.84 & 11.97 \\
\hline & $(4.02)^{\star *}$ & $(3.11)^{* *}$ & $(1.02)$ & $(0.69)$ & $(3.85)^{\star *}$ & $(5.02)^{\star *}$ \\
\hline & 6.70 & 2.51 & 0.65 & -0.93 & -8.52 & 15.22 \\
\hline & $(5.06)^{\star *}$ & $(2.07)^{\star}$ & $(0.58)$ & $(0.85)$ & $(5.89)^{* *}$ & $(7.07)^{\star *}$ \\
\hline \multirow[t]{2}{*}{ Small } & 5.30 & 2.96 & 1.11 & -3.02 & -12.19 & 17.49 \\
\hline & $(4.36)^{\star *}$ & $(2.41)^{*}$ & $(0.93)$ & $(1.87)$ & $(4.15)^{* *}$ & $(5.81)^{\star *}$ \\
\hline Large - Small & $\begin{array}{c}2.21 \\
(1.23)\end{array}$ & $\begin{array}{l}-2.66 \\
(1.63)\end{array}$ & $\begin{array}{l}-0.71 \\
(0.45)\end{array}$ & $\begin{array}{c}1.44 \\
(0.75)\end{array}$ & $\begin{array}{c}8.11 \\
(2.61)^{\star *}\end{array}$ & \\
\hline
\end{tabular}




\section{Table 8: Double sorting on value and distress}

This table reports mean excess returns over the market and 3-factor alphas for portfolios sorted on book-tomarket (BM) and fitted 12-month fitted probability of failure (Phat). We first sort stocks into book-to-market quintiles using NYSE breakpoints (following Fama-French) and then, within each quintile, sort stocks into predicted failure probability quintiles. All returns are in annualized percent units.

\begin{tabular}{|c|c|c|c|c|c|c|}
\hline BMIPhat & Low & & & & High & Low - High \\
\hline \multirow[t]{8}{*}{ High } & 4.36 & 3.10 & 6.44 & -1.09 & -4.37 & 8.74 \\
\hline & $(2.41)^{\star}$ & (1.33) & $(2.06)^{\star}$ & $(0.26)$ & $(0.81)$ & (1.51) \\
\hline & 5.69 & 3.88 & 3.26 & 6.71 & -0.66 & 6.35 \\
\hline & $(2.82)^{\star \star}$ & (1.90) & (1.56) & $(2.45)^{\star}$ & (0.16) & (1.28) \\
\hline & 2.55 & 2.15 & 2.25 & 1.12 & -4.43 & 6.98 \\
\hline & $(1.57)$ & $(1.25)$ & (1.29) & $(0.47)$ & (1.30) & $(1.83)$ \\
\hline & 2.70 & -0.27 & -0.42 & -0.84 & -3.26 & 5.96 \\
\hline & (1.33) & (0.23) & (0.29) & (0.34) & (0.90) & (1.23) \\
\hline \multirow[t]{2}{*}{ Low } & 3.77 & -0.30 & -3.38 & -5.96 & -10.62 & 14.39 \\
\hline & $(1.72)$ & $(0.19)$ & $(1.76)$ & $(2.29)^{*}$ & $(2.81)^{\star *}$ & $(3.01)^{\star *}$ \\
\hline High - Low & $\begin{array}{c}0.59 \\
(0.18)\end{array}$ & $\begin{array}{c}3.40 \\
(1.07)\end{array}$ & $\begin{array}{c}9.82 \\
(2.80)^{\star *}\end{array}$ & $\begin{array}{c}4.86 \\
(1.16)\end{array}$ & $\begin{array}{c}6.24 \\
(1.43)\end{array}$ & \\
\hline
\end{tabular}

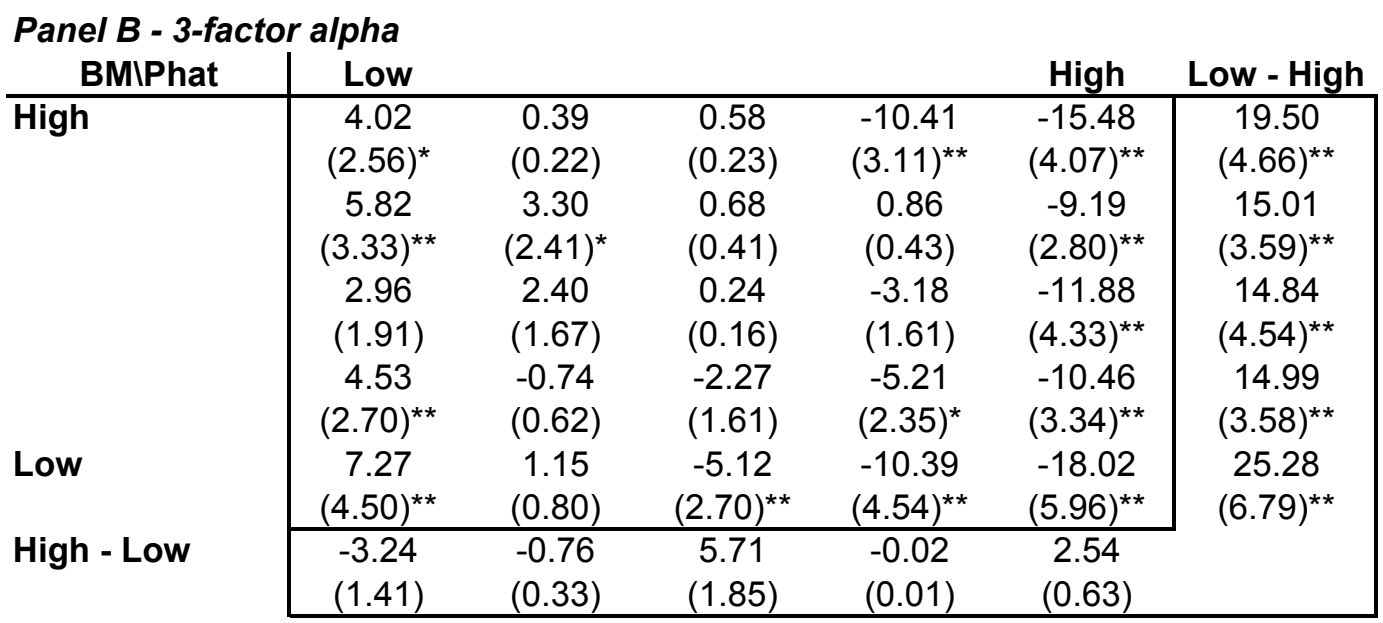




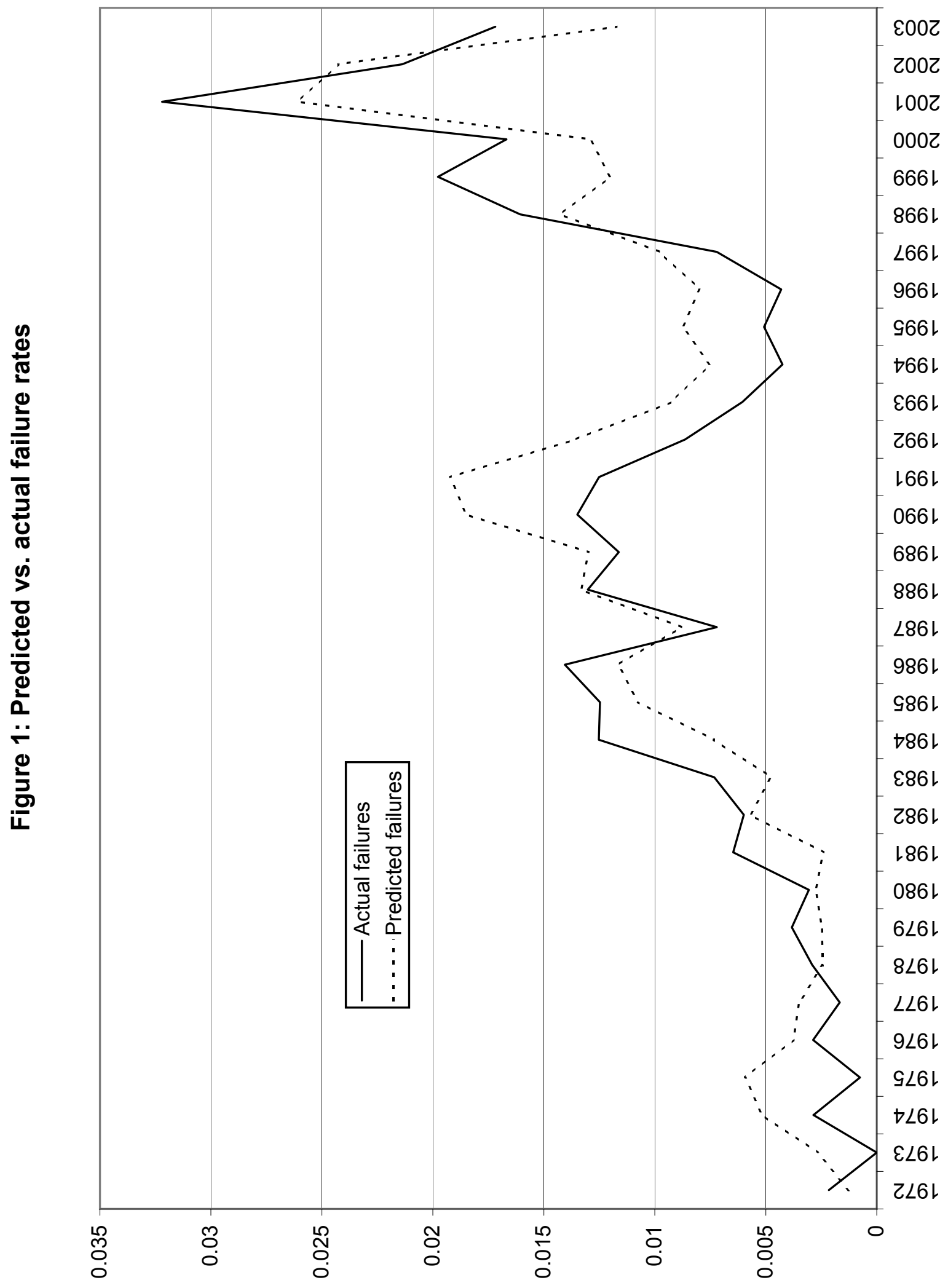




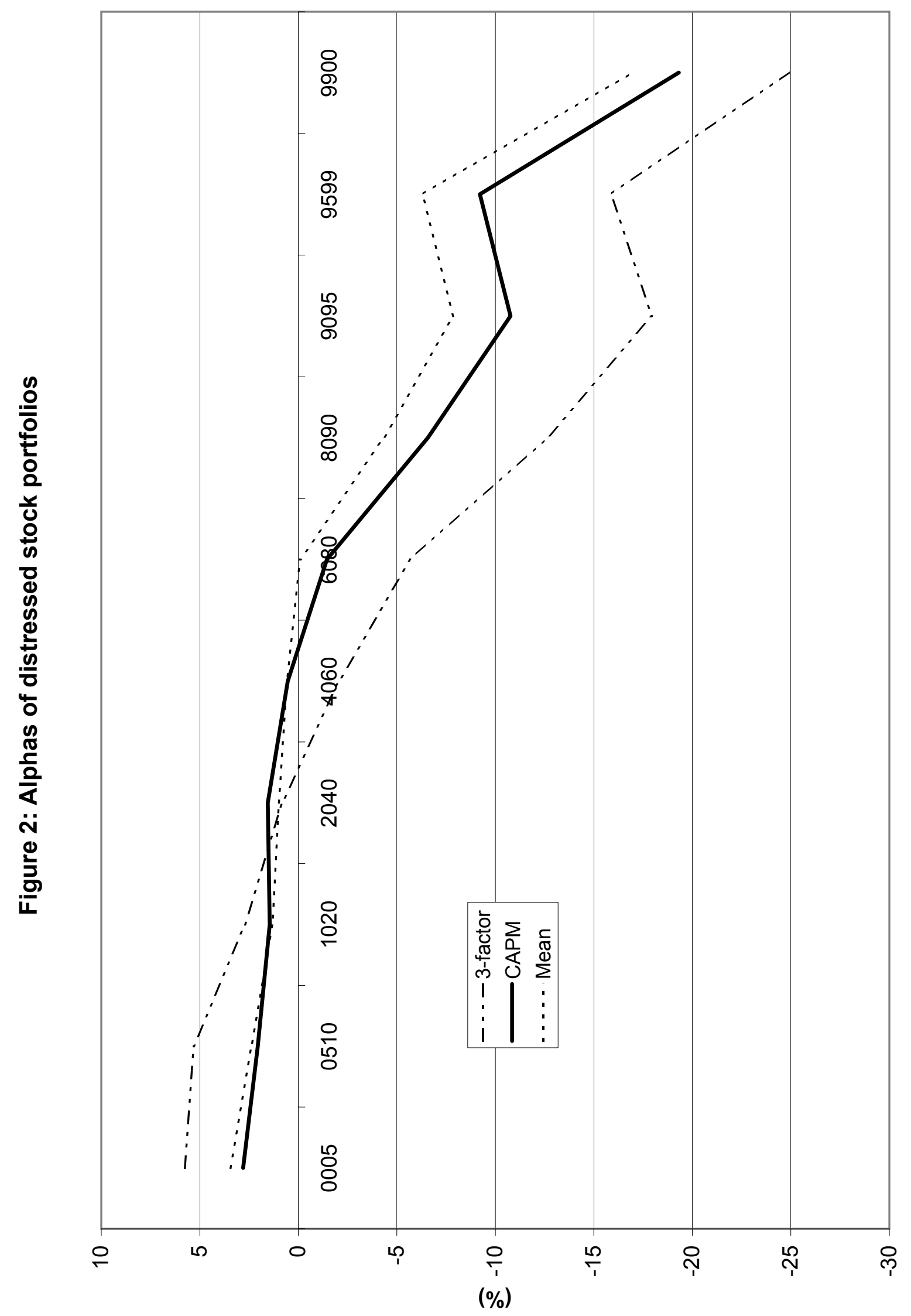




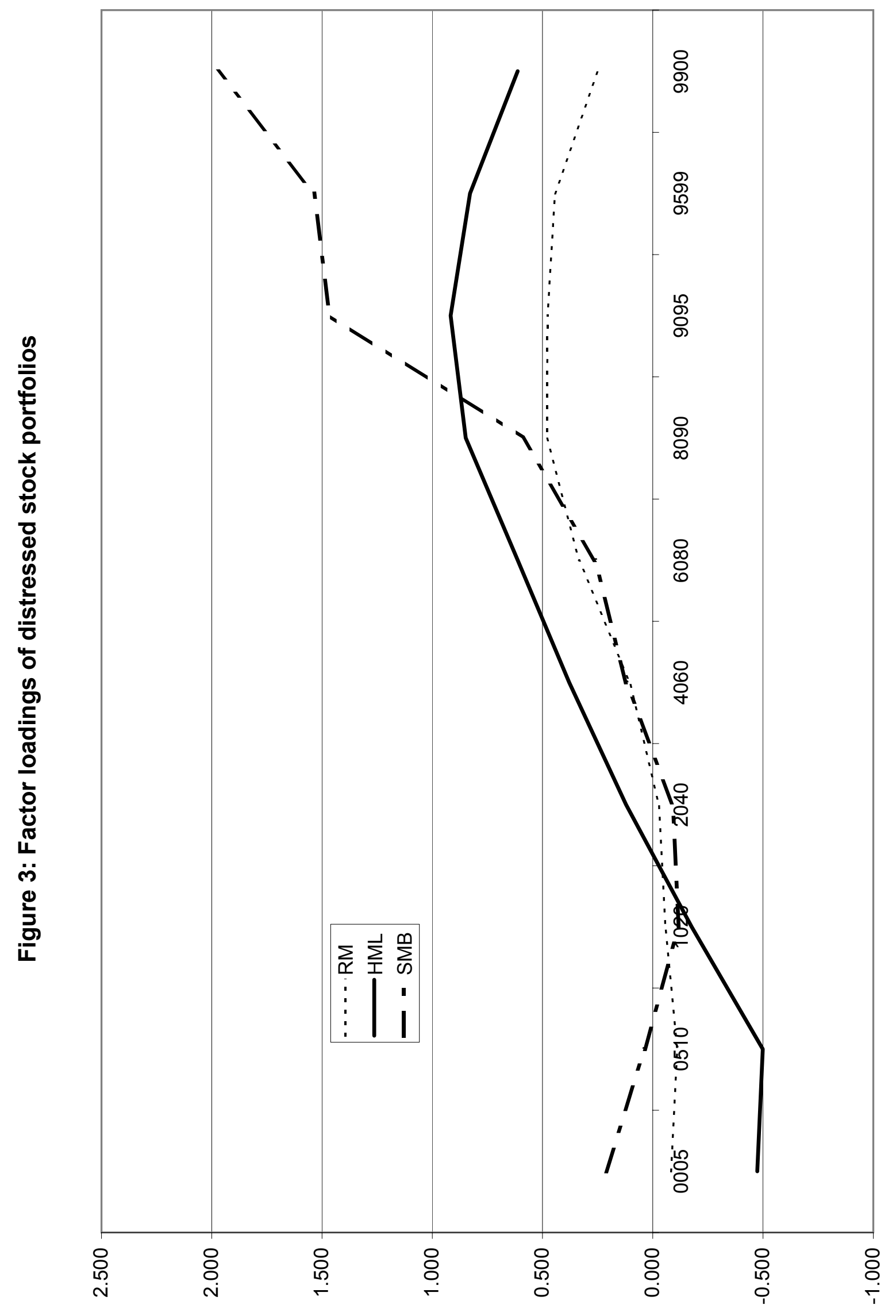




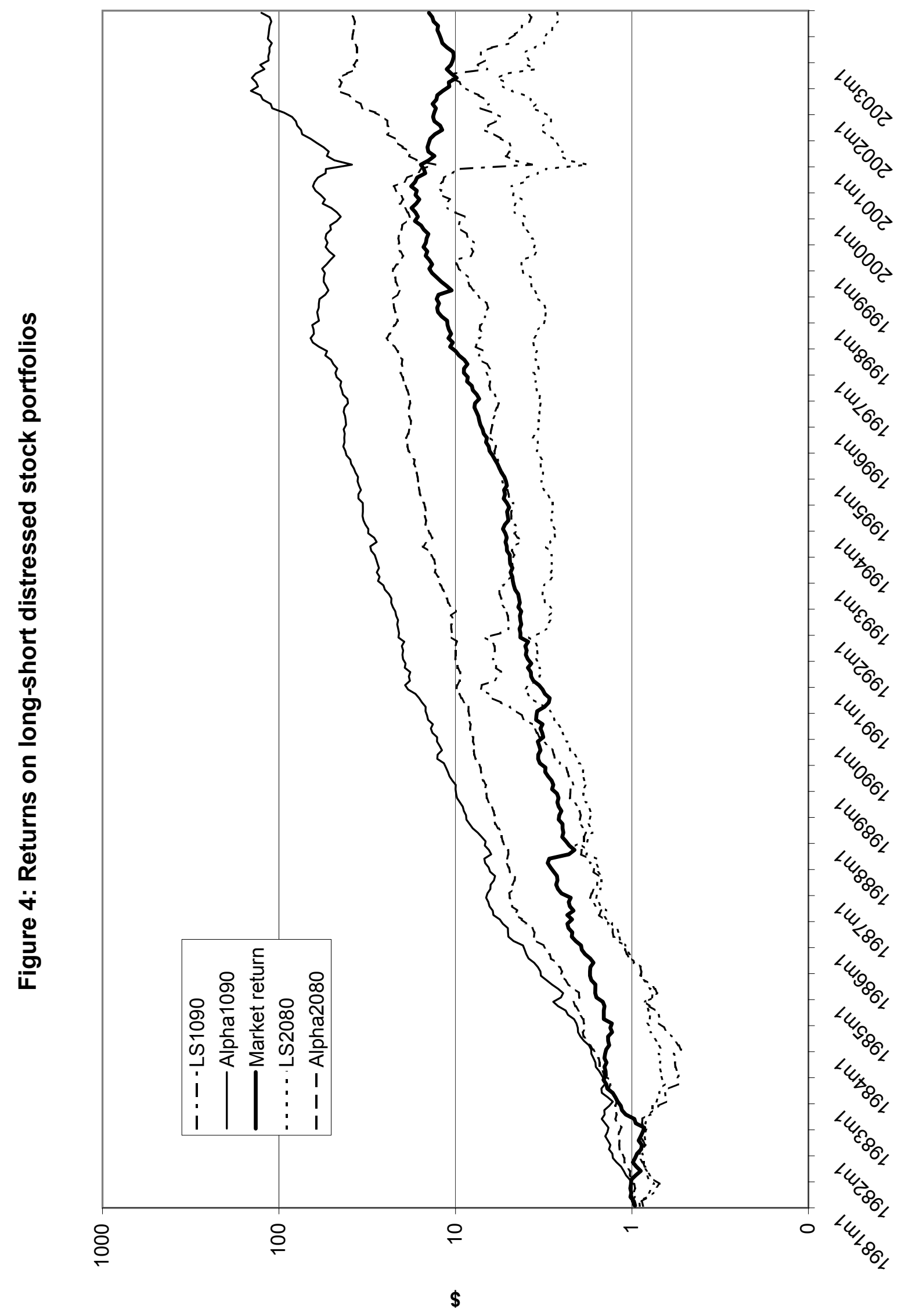

